\title{
STUDY OF THE EFFECTS \\ ON EMPLOYMENT OF PUBLIC AID TO RENEWABLE ENERGY SOURCES
}

\author{
GABRIEL CALZADA ÁLVAREZ* \\ RAQUEL MERINO JARA* \\ JUAN RAMÓN RALLO JULIÁN* \\ JOSÉ IGNACIO GARCÍA BIELSA*
}

Resumen: La crisis económica ha planteado la cuestión de si los gobiernos deberían controlar la economía para promover la prosperidad y crear empleo. Esta idea ha surgido especialmente en relación a la promoción de sectores productivos enteros que se consideran estratégicos o de alto valor por los planificadores, como el sector de las energías renovables. Este artículo analiza la experiencia española en relación con la subvención de las energías eólica, hidroeléctrica y fotovoltaica para impulsar el crecimiento y crear los llamados «empleos verdes». Los resultados sugieren que se destruyen más empleos de los que inicialmente se pretendía crear.

Palabras clave: Energías renovables, subvenciones, destrucción de empleos, planificación económica, estímulos de gasto.

Clasificación JEL: E24; E32; H25; H44; O13; Q42; Q43; Q48.

Abstract: Economic crisis has raised the topic of whether governments should control the economy in order to promote prosperity and create jobs. This idea has specially sprung in relation to the promotion of entire productive sectors which are considered strategic or high-value by planners, one of which is renewable energies. This article analyzes the Spanish experience on subsidizing wind, mini-hydroelectric and photovoltaic energies in order to foster growth and create so-called "green jobs». Results suggest that more jobs are destroyed than those that initially were intended to be created.

* Universidad Rey Juan Carlos.

Procesos de Mercado: Revista Europea de Economía Política Vol. VII, n. ${ }^{\circ}$ 1, Primavera 2010, pp. 13 a 70 
Key words: Renewable energies, subsidies, job destruction, economic planning, spending stimulus.

JEL Classification: E24; E32; H25; H44; O13; Q42; Q43; Q48.

\section{I \\ THE GREEN JOB PHILOSOPHY}

On January 16th, 2009, president-elect Barack Obama visited an Ohio business that manufactures components for wind power generators. Under the watchful eyes of both factory workers and the press, Obama assured, amid deepening unemployment and the onset of one of the gravest economic crises in recent history, that renewable energy «can create millions of additional jobs and entire new industries.» ${ }^{1}$

The president then defended his energy subsidy package by citing examples from other countries: "And think of what's happening in countries like Spain, Germany and Japan, where they're making real investments in renewable energy. They're surging ahead of us, poised to take the lead in these new industries.»

But the benefits, according to Barack Obama, will only be achieved «if we act right now.» The president expressed awareness that certain indicators suggest that «half of the wind projects planned for 2009 could wind up being abandoned because of the economic downturn». If that were to happen, he said, «think about all the businesses that wouldn't come to be, all the jobs that wouldn't be created, all the clean energy we wouldn't produce.»

The president is surely motivated by concern over the social pariah of unemployment, and every president seeking to work on behalf of his country must make often difficult decisions driven by a desire for the economy to generate employment. Furthermore, Obama correctly states the problem in counterfactual ${ }^{2}$

\footnotetext{
1 Speech by president Obama at a wind turbine plant in Bedford Heights, Ohio: http://www.cbsnews.com/blogs/2009/01/16/politics/politicalhotsheet/entry4727659. shtml.

${ }^{2}$ Counterfactual analysis in economic science refers to the study of comparative courses of observable action (after their occurrence) against alternate courses of action
} 
terms. Of importance, as the French economist Frédéric Bastiat said, is not just what is seen but also what is unseen.

When we spend money to build a fast food restaurant instead of solar panels, the cost of this course of action is all of the panels that were never built and all of the jobs in that industry that were never created. Similarly, if the government decides to spend taxpayer money on windmills or solar panels, their unseen cost would be all the hamburgers not cooked or any other productive activity that would no longer take place as a result of the state directing resources to windmills or solar panels. Policymakers must recognize that because of government action, other jobs are not created.

Of course other studies including by U.S. academics have also noted several related impacts, for example:

— Raising energy costs kills. According to a Johns Hopkins study, replacing three-fourths of U.S. coal-based energy with higher priced energy would lead to 150,000 extra premature deaths annually in the U.S. alone (Harvey Brenner, «Health Benefits of Low Cost Energy: An Econometric Case Study,» Environmental Manager, November 2005).

- Reducing emissions, a major rationale for «green jobs» or renewables regimes, hits the poorest hardest. According to the recent report by the Congressional Budget Office, a cap-andtrade system aimed at reducing greenhouse gas emissions by just $15 \%$ will cost the poorest quintile $3 \%$ of their annual household income, while benefiting the richest quintile («Trade-Offs in Allocating Allowances for CO2 Emissions», U.S. Congressional Budget Office, Economic and Budget Issue Brief, April 25, 2007).

- Raising energy costs loses jobs. According to a Penn State University study, replacing two-thirds of U.S. coal-based energy with higher-priced energy such as renewables, if possible, would cost almost 3 million jobs, and perhaps more than 4 million (Rose, A.Z., and Wei, D., «The Economic Impact

that are not seen because the choice of action prevents their taking place. For more on counterfactual analysis in economic science, Hülsmann (2003). 
of Coal Utilization and Displacement in the Continental United States, 2015,» Pennsylvania State University, July 2006).

The latter point is the principal focus of this study, an analysis that quantifies actual net job creation in renewable energy resulting from government aid, to the detriment of alternate uses. $^{3}$ In other words, we attempt to identify how many unseen jobs are lost for each one created - those that are seen - thanks to government aid to green energy.

\section{The European tradition of government aid to create «green jobs»}

Europe's current policy and strategy for the support of so-called renewable energy dates to 1997. On November $26^{\text {th }}$ of that year, the European Commission presented the «White Paper for a Community Strategy and Action Plan» titled «Energy for the future: renewable sources of energy.» ${ }^{4}$ In presenting this European aid scheme barely five days before the Kyoto conference (Third Conference of the Parties to the United Nations Framework Convention on Climate Change), where the signing of a $\mathrm{CO} 2$ rationing accord had already been foreseen, the European Union wanted to get ahead of events and opt for a transformation of its energy model in order to reach the then-stated goal of reducing its greenhouse gas emissions by 2010 to $15 \%$ below 1990 levels. ${ }^{5}$

The White Paper's starting point is that renewable energy sources «are currently unevenly and insufficiently exploited in the European Union.» ${ }^{6}$ At the time, those forms of energy production comprised less than $6 \%$ of the entire consumption of

3 We also note the publication, as this report was being finalized, of an assessment questioning the assumptions, findings and methodologies of the prevalent projections of «green jobs» schemes. Morriss, Bogart, Dorchak, Andrew and Meiners (2009).

4 European Commission (1997a).

5 European Commission (1997b; 1997c).

6 European Commission (1997a, 4). 
energy. The document established the ambitious goal of transforming the state of affairs through an artificial stimulus such that by 2010 the EU would have doubled the contribution of renewables to achieve nearly $12 \%$ of the Union's energy consumption. If we realize that in 1997 the funding to renewables to achieve $6 \%$ of its energy production already included large hydroelectric producers, and that hydro energy had little room to grow due to environmental issues, we quickly understand just how ambitious this project is.

That is to say that, taking into account certain, often material geographic and economic distinctions, Europe had already implemented, at some cost, a «green jobs» agenda like that now proposed in the U.S., and sought to increase it further.

The familiar argument in favor of political action to support the massive development of renewable energy, as now popularized by president Barack Obama, had already been made: «Development of renewable energy sources can actively contribute to job creation, predominantly among the small and medium sized enterprises which are so central to the Community economic fabric, and indeed themselves form the majority in the various renewable energy sectors. Deployment of renewables can be a key feature in regional development with the aim of achieving greater social and economic cohesion within the Community.»7

Thus, in 1997 the creation of jobs in the «renewables» industry emerged as one of the main justifications and focal points of the plan. The authors of the report estimated that between 500,000900,000 new jobs would be created. The White Paper states that «while it is not possible to reach any hard conclusions as is the likely cumulative level of job creation which would derive from investments in the various forms of renewable energy sources, it is quite clear that a pro-active move towards such energy sources will lead to significant new employment opportunities.» ${ }^{8}$ What the White Paper does not clarify is the relationship between the new job opportunities that «would derive from investments in the various forms of renewable energy sources» and those that would not be created or that would

\footnotetext{
7 European Commission (1997a, 4).

8 European Commission (1997a, 13).
} 
be destroyed in other parts of the economy precisely because the funding diverted to renewable energy.

\section{Europe moves to create new employment opportunities}

On September $27^{\text {th }}, 2001$, under the policies and recommendation of the White Paper, the European Union approved Directive 2001/77/CE of the European Parliament and of the Council on the promotion of electricity produced from renewable energy sources in the internal electricity market. ${ }^{9}$

Already aware of the requirements of the Kyoto Protocol, the European Union launched the development of renewable energy by aiming for «the global indicative target of $12 \%$ of gross domestic energy consumption by 2010» through the use of renewable sources of energy, as part of which an objective for the electricity sector is added later on that year, a «22.1\% indicative share of electricity produced from renewable energy sources.» ${ }^{10}$ Already at its inception, the directive states that, beyond its environmental objective, the proposal «can also create local employment.»

That same year the Monitoring and Modeling Initiative on Targets for Renewable Energy (MITRE) project was set out by the European Commission "to confirm the view that the European Union renewable energy targets [were] achievable, and to inform key policy and decision makers of the economic (employment) benefits of a proactive renewable strategy in order to meet the targets.»11 The project ran for two years and its main conclusion was a projected net employment growth in the European Union of 950,000 jobs under current policies, and up to 1,660,000 under the Advanced Renewable Strategy (ARS) of meeting $22.1 \%$ share of electricity produced from renewable energy sources by 2010 . The authors of this study led by Energy for Sustainable Development

9 Directive 2001/77/EC (2001)

10 Directive 2001/77/CE (2001, art. 3).

11 Monitoring \& Modelling Initiative on the Targets for Renewable Energy (MITRE) (2003). 
(ESD) Ltd., a global market leader in the provision of low carbon energy and sustainable development solutions, concluded that «a more pro-active encouragement of renewable gives rise to significant employment gains.»12

On January $10^{\text {th }}, 2007$, the Commission presented an energy and climate policy package the expected repercussions of which were far from modest. According to the Commission itself using language of the sort now employed in the U.S., the package would «set the pace for a new global industrial revolution.» At the European summit in March, 2007, an agreement was adopted mandating certain EU-wide binding targets that the Commission would attempt to implement, to achieve $20 \%$ of total energy consumption in the European Union by 2020. In November of the same year the Commission released its «Strategic Energy Technology Plan» and in January of 2008 the Commission proposed a directive that included objectives for each country, so that the common goal of the plan could be reached. ${ }^{13}$ During the March 2008 European Union summit, an agreement was reached to adopt an energy and climate measure package by the end 2008 which would replace the measures from the 2001 directive. In September the package passed the Industry Committee of the European Parliament with almost unanimous support, and on December 17 th this new directive was approved, substituting for the measures and objectives from the 2001 directive.

According to the new directive, each member state must implement its own share of renewable energy so that the European Union can achieve, by 2020, the goal of going from a total of $8.5 \%$ (in 2005) renewable energy to $20 \%$. Each country of the Union thereby promised to increase its share of renewable energy production by at least $5.5 \%$ from 2005 levels, calculating the rest of the increase based on gross domestic product. Spain's objective requires moving from an $8.7 \%$ renewable energy level in 2005 to $20 \%$ by 2020.

12 Monitoring \& Modelling Initiative on the Targets for Renewable Energy (MITRE). $(2003,13)$.

13 COM (2008). 
The directive's explanatory memorandum highlights the argued benefits of the job creation in knowledge-based industries. The document reiterates the thesis that the "promotion of investments in energy efficiency, renewable energy and new technologies contributes to Europe's strategy for knowledge and employment.»

The creation of green jobs would this time become the proposal's principal rationale. On January $23^{\text {rd }} 2008$, the very same day that the Commission proposed the package in the new directive, Commission President José Manuel Barroso said that the proposal would be "an opportunity that should create thousands of new businesses and millions of jobs in Europe. We must grasp that opportunity.» The same idea was repeated, albeit with different tones, by various political leaders, giving fodder to a press release by the Commission that captured comments by its members under the title, «Boosting jobs and growth by meeting our climate change commitments.» ${ }^{14}$

Not everyone, however, succumbed to the Commission's euphoria for the directive's job-creation potential. The same day, the European Trade Union Confederation (ETUC) sent out a release recognizing the important step taken by the Commission but warned of the necessity to guarantee European jobs in a globalized world. That is to say that the union syndicate saw the potential risk of employment destruction due to the package's "green energy» requirements and other measures, and thus clamored for the passing of a «compensation mechanism» to guarantee employment to Europeans in the heavy industry sector.

The release recommended that the "Globalisation Adjustment Fund be enlarged so as to limit the negative consequences for workers of measures to combat climate change.» ${ }^{15}$ The jobs negatively affected would not be new green jobs, of course, but the less visible ones that would be destroyed due to mandates, loss of competitiveness, and reallocation of resources. The ETUC could have gone further still if only it had, like Obama, considered

\footnotetext{
14 European Commission (2008).

15 European Trade Union Confederation (2008a).
} 
in its statement those positions that simply would cease to be created in other industries.

This same confederacy of European unions again declared its bittersweet impression over «the objectives of reducing greenhouse gas emissions by $20 \%$ and increasing the share of renewable energy to 20\%» after the December 12 confirmation by the European Council. ETUC welcomed the agreement while also «regretting the lack of accompaniment measures for workers affected by the consequences.» Furthermore, the organization doubts, given the current circumstances, the "EU's financial capacity to invest sufficiently in the 27 countries to reduce $\mathrm{CO}_{2}$ emissions and promote renewable energy sources.» ${ }^{16}$

\section{Background to Case Study: Policies in Spain}

As Obama correctly remarked (and we will study in the next section), Spain provides a reference for the establishment of government aid to renewable energy. Indeed, the special regime, ${ }^{17}$ under which renewable energy is juridically differentiated, has been regulated in Spain since 1980 when Law 80/1980 on Energy Conservation was enacted.

Royal Decree 2366/1994 was published in December of 1994. It dealt with electrical production by hydroelectric installations and with cogeneration and other installations that make use of sources of renewable energy; this decree constitutes an initial feedin tariff scheme (which has the effect of artificially increasing the price paid for electricity produced by renewables) for production with renewable sources. Over the years, Royal Decrees ${ }^{18}$ and laws

\footnotetext{
16 European Trade Union Confederation (2008a).

17 «The generation activity in Special Regime includes the electric energy generation from power plants up to $50 \mathrm{MW}$ which make use of renewable energies or wastes as primary energy, and those such as cogeneration that involve the utilization of high efficiency and energy saving technologies». Ministerio de Industria, Turismo y Comercio, at http:/ / www.mityc.es/energia/electricidad/RegimenEspecial/Paginas / Index.aspx.

18 Executive order formally sanctioned by the King (typical in monarchical countries, such as Spain).
} 
would continue to emerge, and with them, government support to these kinds of energy production.

Royal Decree 436/2004 ${ }^{19}$ was approved in March of 2004, establishing the methodology for updating and systematizing the legislative and economic system of electric energy production under the special regime. The rule renewed and strengthened public assistance to renewable energy with retributions above a «mean reference rate» ${ }^{20}$ of up to $575 \%$ for solar photovoltaic plants and up to $90 \%$ for wind-based electric installations. During the 2004 general election campaign the socialist candidate, José Luis Rodríguez Zapatero, promised «a reorientation of the energy model (...) towards one that is more centralized, more diversified and safe, less wasteful and also more solidary» (meaning it requires payment by many into a system «for the common good» from which they achieve little benefit). It was a change in energy policy that would take place - and this is paramount - «built on all renewables, and in particular, solar energy.» ${ }^{21}$ As we shall see in the next sections, the government's zeal to impel renewable energy led to strong growth in the industry and in related employment.

The Royal Decree currently in place is $661 / 2007,22$ which establishes the methodology for updating and systematizing the legislative and economic regime of electric energy production under the special regime. The new method continues to heavily support renewable energy. Wind energy producers, for example, received $€ 73.22 / \mathrm{MWh}$ (appx. \$92 USD per MWh), which could be anywhere between $136 \%$ and $209 \%$ of the market price at the time. This is relevant because it does appear that such price-hiking

19 Spain. Real Decreto 436/2004.

20 This is a reference rate fixed by the Government for retribution purposes, historically at higher levels than the average market selling price (on many occasions, doubling it).

${ }^{21}$ See http:/ / www.energias-renovables.com/paginas/Contenidosecciones.asp?ID= $14 \& \operatorname{Cod}=4335 \&$ Tipo $=$ historico $\&$ Nombre $=$ Noticias.

22 With the exception of the remuneration as well as part of the administrative procedures in force for solar photovoltaic plants for installations subsequent to the deadline for the retribution according to the Royal Decree 661/2007, which is currently regulated in those regards by the Royal Decree 1578/2008. 
subsidy is necessary to make renewable technologies in a sense viable.

Soon after approving this new Royal Decree, Prime Minister Zapatero defended the change from the existing energy model to his energy model "of the future» - which Spain would lead, using language similar to that now employed in the U.S. - and correlated his efforts in the promotion of renewables with the creation of a high volume of jobs in the renewable energy sector. History would partially prove him right. The question we address is «at what price?»

\section{II}

THE SPANISH RENEWABLES BUBBLE: WIND AND PHOTOVOLTAIC ENERGY

This section will study two paradigmatic cases in Spain: wind energy and photovoltaic solar energy. ${ }^{23}$

The boom in renewable energy is the result of the confluence of two factors that have reinforced each other in recent years.

In order to enhance renewable energy sources in Spain, the Government promoted legislation the main goal of which is to reach $12 \%$ penetration by these sources in the Spanish energy market and $20 \%$ of electric production in 2010 . There are primarily two mechanisms:

- Setting regulated rates or highly subsided premiums as compared with a mean reference rate, with the clear objective of attracting investment to the relevant sector. In addition, electricity retailers are forced to buy all the electricity generated by renewable sources, which eventually implies that, unlike other forms of production, the sale of renewables output is guaranteed and hence so is the return on the investment.

23 The thermoelectric solar energy is residual in Spain. The only plant (11 MW) was installed in 2008 . 
- Incentives: ICO (Instituto de Crédito Oficial) credits and IDAE (Instituto para la Diversificación y Ahorro de la Energía) aid, to which subsidies from the Spanish regions (Comunidades Autónomas) are added.

The second case is the economic cycle itself, which has clearly propelled the establishment of these technologies in Spain. We shall analyze how interest rates (from the European Central Bank) and the ease with which credit is granted affects Spain along the cycle, as well as the volume of credit that the electric industry receives, particularly through September of 2008, when the photovoltaic industry burst its bubble.

\section{The retributive framework for wind energy}

To achieve the goal of having $12 \%$ of primary energy originated from renewable energy, the Renewable Energy Plan (PER) 20052010 establishes that in 2010,20,155MW of wind power (capacity) must be installed (Table 1).

Spain's National Energy Commission (CNE) estimates that through December of 2008 there might have been as much as 15,617 MW installed, although only $14,836 \mathrm{MW}$ are officially accounted for (Figure 1).

The rate of development of this technology has remained comparatively quite calm (considerably more so than photovoltaic energy, which we shall mention later on). To attract investors and

TABLE 1

EXPECTED WIND ENERGY INSTALLATION GROWTH IN SPAIN ACCORDING TO PER 2005-2010

\begin{tabular}{lllllllll}
\hline & 2005 & 2006 & 2007 & 2008 & 2009 & 2010 & $\begin{array}{c}\text { TOTAL } \\
2005- \\
2010\end{array}$ \\
$\begin{array}{c}\text { Potencia eólica } \\
\text { anual (MW) }\end{array}$ & 1.800 & 2.000 & 2.200 & 2.200 & 2.000 & 1.800 & 12.000 \\
\hline
\end{tabular}

Source: Renewable energy plan 2005-2010. 
FIGURE 1

INSTALLED WIND POWER BY YEAR (1990-2008)

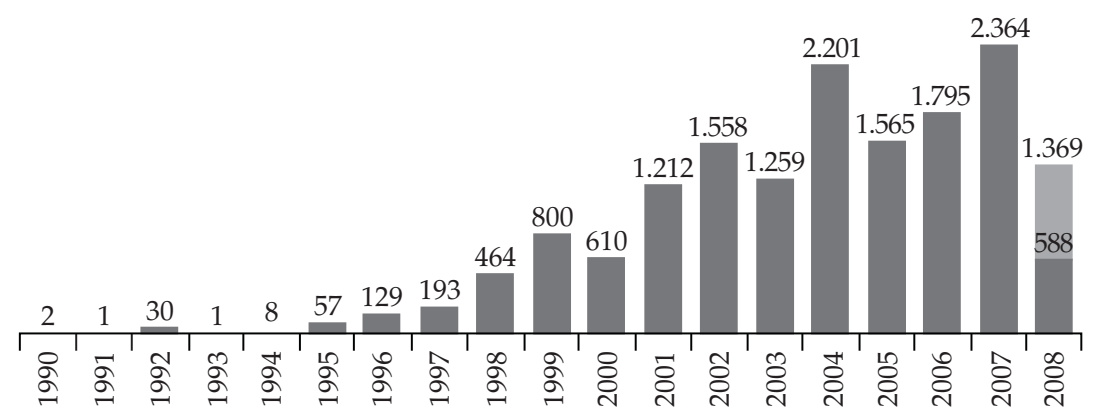

Estimated installed capacity (MW) 2008

Official installed capacity (MW) per year

Source: $\mathrm{CNE}^{24}$ own elaboration.

make it profitable against other forms of energy, it must remain subsidized. However, it has not experienced a bubble as intense as the one experienced by the photovoltaic industry, its annual rate of capacity increase being more in tune with PER's own forecasts for 2005-2010.

Spain has become the world's third-largest country for installed wind energy capacity. The last eleven years have seen three different economic regimes relevant to wind: RD 2818/1998 (19982004), RD 436/2004 (2004-2006) and RD 661/2007 (since 2007).

The effect of the retributive framework on the wind farms has been to achieve sufficient stability in the development of the technology. By using estimated data on installed capacity, CNE projects that by the end of $2008,77 \%$ of the 2010 objective was reached, leaving 40 months to reach the final goal of $20155 \mathrm{MW}$ (Figure 2).

With regards to the objective that $20 \%$ of electric consumption originates from renewable sources by 2010, wind power is the source that contributes the most among the renewables, with

${ }^{24}$ CNE (2009a). 
FIGURE 2

(A) AVERAGE KWH PRICE.

(B) TOTAL RETRIBUTION AND OVER-COST25 (MILL. €) OF WIND ENERGY (1998-2008)
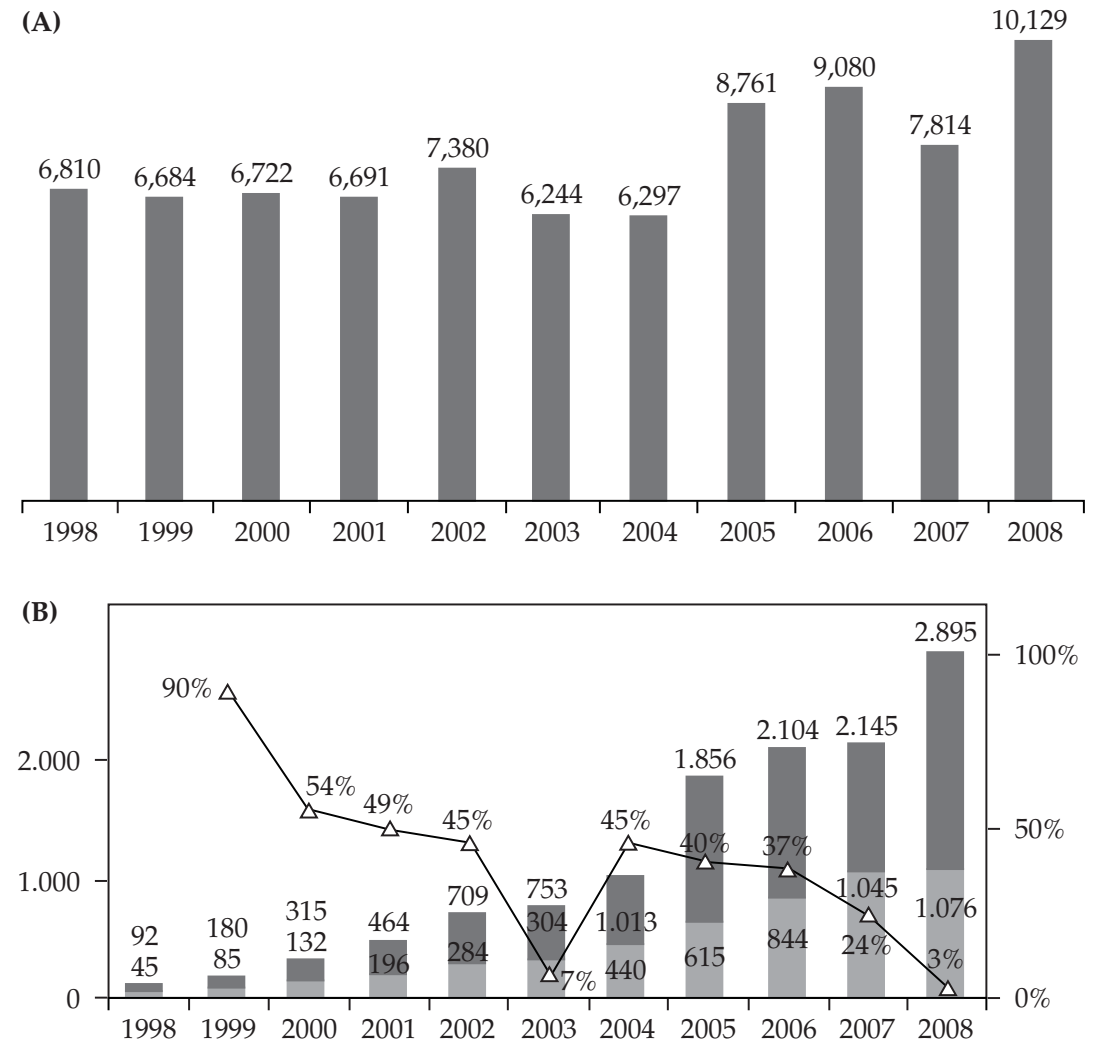

$$
\begin{aligned}
& \text { Wind turnover (in mill. } € \text { ) } \\
& \text { Over-cost related to pool proce (in mill. } € \text { ) } \\
& -\triangle \text { Annual percentage change of over-cost }
\end{aligned}
$$

Source: CNE, own elaboration.

25 This is the amount paid over the cost - because of the feed-in price system that would result from buying the electricity generated by the renewable power plants at the market price (also named «pool price»), i.e., the over-cost is the result of multiplying the production by the difference between the average selling price 
$10.2 \%$ of electric consumption provided by wind ${ }^{26}$ in 2008 . The expansion of this technology, however, has not been the result of economic efficiency but instead of the political pressure to develop it on a massive scale.

The success in the deployment of this energy source must be viewed with the perspective that, although twice as much wind has been installed as the second-leading installed "special regime» technology, cogeneration, the latter sells 3.1 GWh per installed MW while wind energy sells $1.7 \mathrm{GWh}$ per MW installed. That is, cogeneration produces nearly twice the actual electricity per megawatt of capacity constructed (Figure 3).

FIGURE 3

OFFICIAL INSTALLED CAPACITY (MW)

AND PRODUCTION (GWH) TO INSTALLED MW RATIO

FOR TECHNOLOGIES UNDER THE «SPECIAL REGIME» (2008)

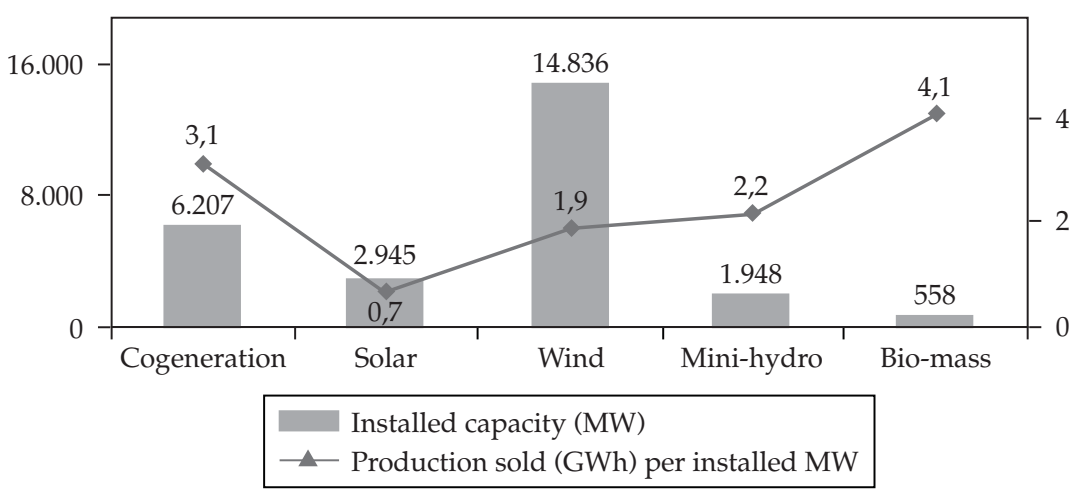

Source: CNE. CNE's official installed capacity data are shown for 2008, since these are the special regime power plants which have actually sold electricity during the cited year. As for the solar energy, we include the only thermoelectrical installation there is in Spain (an 11 MW plant which starts operating in 2008).

of each technology and the average price of the market. Both the average selling price by technology and the average market price are from the cited CNE «Monthly Report on Energy Purchases from Special Regime.» The average market price comes from the monthly settlement of the special regime's installations that take part in the electricity production market (made by OMEL-REE -Red Eléctrica Española).

${ }^{26}$ The total for renewable energy is $19 \%$ in 2008. 
The sold-energy-to-installed-capacity ratio is even lower for solar energy, providing the least among all those technologies taken into consideration with $0.7 \mathrm{GWh}$ sold per installed megawatt. Nonetheless, we can find a partial cause for this phenomenon in the fact that in 2008 alone 2253 megawatts have been officially installed; thereby, many of the plants have not been operating for a full year. The same ratio for solar energy in 2007 amounts to 0.71 GWh/MW.

Although in relative terms the wind bubble has not been as great as the one experienced by solar photovoltaic energy, it is worth noting that the $15617 \mathrm{MW}$ installed is such a high amount that, in the middle of the economic crisis, it will necessarily represent a very significant portion of the electric deficit. ${ }^{27}$

Not without reason, RD 436/2004 was considered by the Secretary of Energy (November 2006 ${ }^{28}$ ) as «unfortunate». The inclusion of the new Royal Decree of 2007 accomplished in part its objective (cut the percentage of over-cost), even though the average regulated sale price increased to its highest levels. The accumulated rate deficit since 2000 is over 15,000 million Euros (appx. $\$ 18.9$ billion USD) and it increased by 5,640 million Euros (appx. $\$ 7.14$ billion USD) in just 2008, according to settlement information ${ }^{29}$ from CNE (see Figure 7).

\section{The retributive framework for photovoltaic solar energy: an unprecedented bubble, a reversal and the burst}

The objectives laid out by PER 2005 for the development of the photovoltaic industry call for $371 \mathrm{MW}$ of capacity by 2010. Solar photovoltaic energy would begin to be massively deployed in Spain from 2004 to 2008. Through that time, three economic

27 The so-called rate deficit of the Spanish electric system is the result of fixed rates over electricity consumption which doesn't cover the cost of production, transportation and distribution, and rest of the costs of the electric system, especially those of the over-cost produced by governmental support of renewable energies.

28 See http:/ / www.eleconomista.es/empresas-finanzas/noticias/99679/11/06/ Industria-fijara-un-tope-maximo-y-minimo-para-primas-de-la-eolica.html.

29 CNE (2009b). 
regimes have come into effect; thanks to the appealing guaranteed retributions, these policies would massively encourage development of the industry, such as President Obama now speaks of. In 2008 Spain would become the second-largest country in installed capacity of solar energy, behind only Germany.

The three Royal Decrees are 436/2004 (2004-2006), RD 661/ 2007 (from June 2007 to September 2008) and RD 1578/2008 (starting on September 29th) (Figure 4).

RD 436/2004 took effect in 2004 when in Spain there were only $12 \mathrm{MW}$ of installed capacity. The current retributive framework aims to considerably increase the deployment of photovoltaic installations with the purpose of achieving the market penetration agreement with the European Union for the electricity (20\%) and broader energy (12\%) markets, all while giving preference

Figure 4

YEARLY GROWTH OF INSTALLED CAPACITY (MW)

OF SOLAR PHOTOVOLTAIC ENERGY (REPORTED AND ESTIMATED) FROM 2004 TO 2008.

INCREASE IN INSTALLED CAPACITY OF PHOTOVOLTAIC PLANTS UP TO $100 \mathrm{KW}$

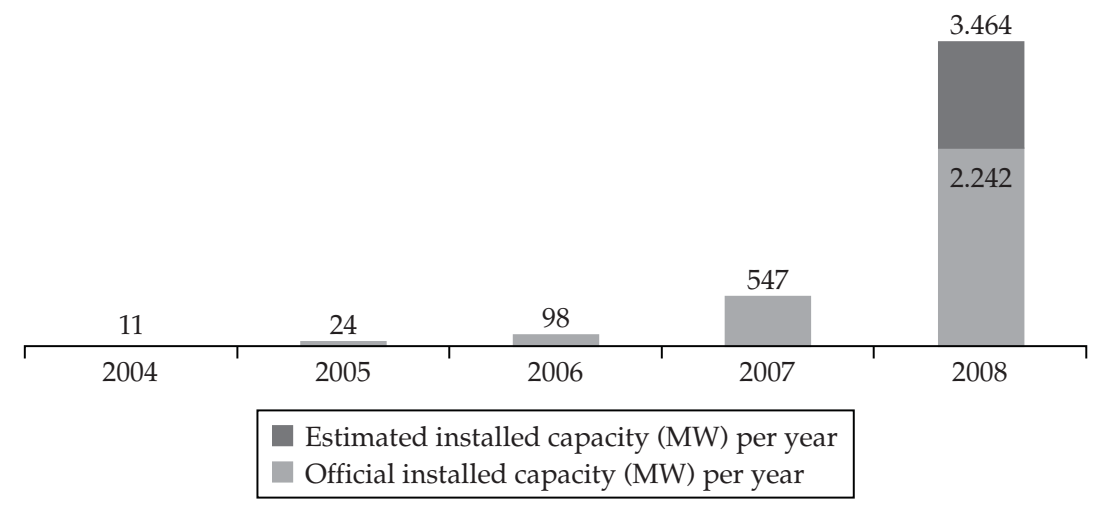

Source: CNE. ${ }^{30}$

30 CNE (2009a). 
to the smaller investors. To that end, a scheme of progressive regulated rates is established according to the size of the plant: $575 \%$ above the mean reference rate $\left(\mathrm{TMR}^{31}\right)$ during the first 25 years of operation for plants up to $100 \mathrm{~kW}$. Higher capacity plants, however, are penalized with a retribution over the TMR of «only» $300 \%$ in the first 25 years.

Nonetheless, as is common with such schemes this only emboldens craftiness. Indeed, in order to take advantage of the $575 \%$ over TMR, «solar farms» of various MW started to proliferate, motivated by businesses which ran these installations under several clients' names, usually assigning to teach one less than the $100 \mathrm{~kW}$ limit. Thus, these firms could manage a big solar farm (for example, 10MW) connected by a series of transformers up to $100 \mathrm{~kW}$ each.

In short, such artificial subsidy schemes encourage massive inefficiencies, which increase the «renewable» requirements economic cost.

Not surprisingly, the annual growth rate of plants of up to 100 $\mathrm{kW}$ reached $122 \%$ both in 2004 and 2005, and 215\% in 2006, with photovoltaic capacity going from $9 \mathrm{MW}$ at the beginning of 2004 to $140 \mathrm{MW}$ at the end of 2006. Regarding plants above $100 \mathrm{~kW}$, these start out at $3 \mathrm{MW}$ at the beginning of 2004 and end up with $5 \mathrm{MW}$ in 2006. It is within this context that many a rentseeker began to reel in such a juicy catch, from large family estates, venture capital and large corporations (Repsol, Iberdrola, Gamesa) to large financial institutions (BBVA, Banco Santander, La Caixa, CAM, Barclays, Deutsche Bank, etc.) willing to loan money to secure state-guaranteed returns.

31 TMR used to be set by the Government every year. This 'mean reference rate' should not be confused with the average market price (also called pool price), since the first was a political price fixed by the Government for retribution purposes and was commonly higher than the pool price. For example, in 2004, TMR amounted to $7.2072 \mathrm{c} € / \mathrm{kWh}$ while the pool price reached $3.565 \mathrm{c} € / \mathrm{kWh}$. That ultimately means that a 575\% rate above the TMR implied, by 2004, twice the percentage remitted to «photovoltaic» electricity providers in terms of the pool price, i.e., plants up to 100 $\mathrm{kW}$ received subsidies representing $1162 \%$ of the average pool price. 


\section{The bubble: September $29^{\text {th }}, 2007$ through September $29^{\text {th }}, 2008$}

RD $661 / 2007$ took effect on June $1^{\text {st }} 2007$. This new directive aimed to create continuity and stability in the solar sector, even though the main difference it offered lies in the attempt to control an unintended consequence already caused by a previous regulation: the exorbitant development of the aforementioned "solar farms" and the dubious shadow of influences that they had cast.

The photovoltaic retributive framework then unlinks from the TMR retribution and, instead, a fixed reference price is set (whose 2007 initial value is published in the RD), and will be updated yearly against the consumer price index (CPI).

To seek greater professionalism in this sector, installations of more than $100 \mathrm{~kW}$ would no longer be intrinsically discouraged. Thus, those plants willing to welcome the regulated rate retributive framework and with capacity up to $100 \mathrm{~kW}$, would receive $44 \mathrm{c} € / \mathrm{kWh}$ for the first 25 years. Plants between $100 \mathrm{~kW}$ and $10 \mathrm{MW}$ would receive 41.75 cents per kilowatt-hour sold. Furthermore, both rates will be updated annually according to the CPI.

In September of 2007, the National Energy Commission ${ }^{32}$ (CNE) certified that, as of information available through that August, 85\% of the $371 \mathrm{MW}$ goal towards 2010 had been reached. Furthermore, the CNE assured that the full objective could be attained by October 2007.

The announcement of the completion of $85 \%$ of the objective in 2007 immediately triggered the necessity to craft a new Royal Decree that would regulate rates and set operating conditions during a prescribed period of time, which was determined to be one year. The transitional period of one year was chosen to allow installations being built to have enough time to finish construction

32 According to CNE, reliable data of installed capacity in the case of photovoltaic technology is very inferior to that of the rest of renewable energy sources. Therefore, at $\mathrm{n}+1$ (referring to month $\mathrm{n}$ ), the official records only gather a $70.6 \%$ completion of real capacity. 
and come into operation (10 months on average), thereby taking advantage of the rates and regulations from RD 661/2007.

The draft of the Royal Decree dated September 27th 2007 revised the power objective that must be installed by 2010, increasing it to $1200 \mathrm{MW}$. All installations beginning during the transitional period, once the new limit of $1200 \mathrm{MW}$ was exceeded, would receive a non-subsidized retribution until the new RD took force, and with it, new rates.

The CNE would later ask to modify the draft and is finally able to require all installations which signed up before September $30^{\text {th }}, 2008$, to abide by the new retributive framework (decree 661), regardless of whether the goal of $1200 \mathrm{MW}$ was met.

A period of uncertainty then arose in anticipation of the new regulation that would take effect one year after the transitional period (September 2008), which investors presumed would most likely prove to be less beneficial. Investors, thus, were motivated to rapidly install as much power as possible before September $29^{\text {th }}, 2008$, fearing that the upcoming regulation would be much worse.

Such is the source of the boom in the installation of new solar photovoltaic plants that, according to official records published by the $\mathrm{CNE}^{33}$, through December of 2008, the scheme yielded over $2934 \mathrm{MW}$ of solar photovoltaic power in place. However, according to $\mathrm{CNE}^{\prime}$ s own estimates ${ }^{34}$, it could have realistically reached up to $4156 \mathrm{MW}^{35}$, which would mean that an $83.3 \%$ of the overall capacity was installed in 2008 alone.

The new retributive framework extends the generosity of the regulated rates for larger installations: those above $100 \mathrm{~kW}$ and under $10 \mathrm{MW}$ will enjoy for 2009 a regulated price of 44.5751 $\mathrm{c} € / \mathrm{kWh}$, and $47.0181 \mathrm{c} € / \mathrm{kWh}$ for those plants up to $100 \mathrm{~kW}$. Moreover, the one-year grace period allows investors to install as

\footnotetext{
33 Solar plants which are already billing to distributing companies.

$34 \mathrm{CNE}$ takes into account the average delay in receiving the registry data of the installations in operation within a period. According to $\mathrm{CNE}$, not until 9 months have passed since they start to measure the number of plants installed in a month that they have a reliability of a $95.8 \%$.

35 Available on the worksheet named «Cumplimiento Objetivo» in the "Monthly Report on Energy Purchases from Special Regime» (Jan 2009 referred to Dec 2008).
} 
much power as possible before it ends, thereby joining en masse photovoltaic plants in the $100 \mathrm{~kW}-10 \mathrm{MW}$ range (Figure 5).

The graph above shows the strong yearly growth in power plants above $100 \mathrm{~kW}$ capacity. According to official data, there was growth in solar capacity of 806\% in 2007 and 903\% in 2008. If we extrapolate from CNE's estimates, growth in 2008 could have reached as high as $1315 \%$.

The attempt to encourage stability and «professionalism» in the industry by ensuring strong market penetration by specialized participants (especially to exploit higher capacity plants) in the

FigURE 5

2006-2008 YEARLY INSTALLATION OF SOLAR

PHOTOVOLTAIC POWER (IN MW) BY PLANT SIZE

AND CUMULATIVE RATE OF GROWTH

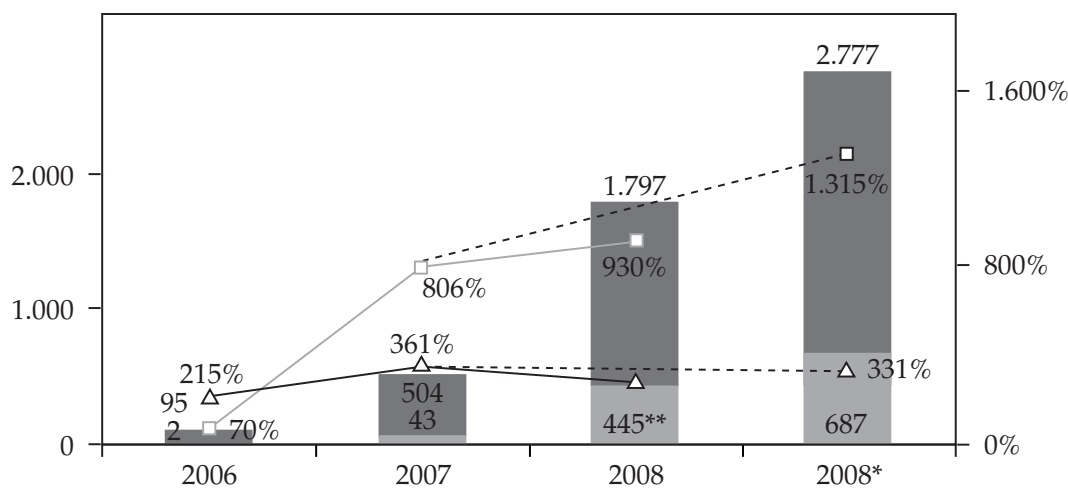

2008

$2008^{*}$

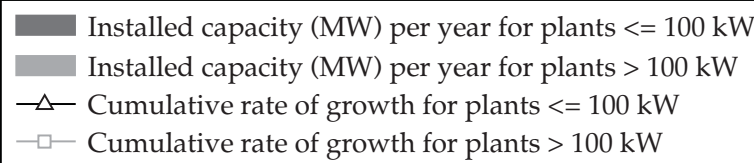

«2008*» refers to data extrapolated from the total potential amount of power estimated by the CNE in 2008. The «2008» column, however, represents the 2008 official installed capacity that the CNE accounts for at the beginning of 2009 (which is still incomplete).

** The first and only thermal solar plan is in Spain is brought online in 2008, with a capacity of $11 \mathrm{MW}$ of power. The graph only takes into account photovoltaic solar energy and thus those $11 \mathrm{MW}$ are not added to the official $445 \mathrm{MW}$ seen above. 
production of photovoltaic energy, however, has not reaped the expected benefits. Instead, the energy industry witnessed the entrance of builders, real estate companies, hotel groups and even truck manufacturers.

The regulated tariffs are so generous that, by leveraging $70 \%$ of the cost, a $100 \mathrm{~kW}$ photovoltaic plant would yield internal rates of return of up to $17 \%$ in $2007 .{ }^{36}$ To put what this figure implies into perspective, let's compare it with a bond. Currently, a 30 year Spanish bond is yielding a return rate close to $5 \%$ per year. A solar plant investment would obtain 1,200 more basis points with a similar risk and guarantee (the one offered by Spanish Sate). Another way to understand the magnitude of this result is to calculate the earnings an investor initially endowing 100,000 euros would gather, reinvesting principal and interest yearly at the same $17 \%$ internal return rate. In 25 years, stemming from those 100,000 euros, the investment would become 5,065,782 euros.

Even the Photovoltaic Solar Industry Association (ASIF), through its president, Javier Anta, mentioned that, among other factors, "the ease of credit, a photovoltaic rate - the one from RD 661/07 -, which was left high,» have contributed such that the growth this produced in Spain's industry has absolutely exceeded all expectations and is now the world's number one photovoltaic market, even ahead of Germany.» ${ }^{37}$

The latter factor is an important one for U.S. policymakers to consider as they expressly seek to replicate superficial tales of the European - and specifically Spanish - experience with renewable energy policy regimes by seeking to artificially force massive growth.

36 Own estimate based on a turnkey project that had been settled in 2007 (RD $661 / 2007$ retribution). Despite not being included here, we have used the estimation of a turnkey project (offered by Solar Fotovoltaicas Consulting corresponding to 2005 investment costs) to compare the approximate yield under three different retribution frameworks. We are not even considering public aids, such as those offered by ICO-IDAE or local/regional institutions, which would have turned the internal returns higher.

37 Statements can be found on Energías Renovables' website and other media. See: http://www.energias-renovables.com/paginas/Contenidosecciones.asp?ID= $14 \& \operatorname{Cod}=15756 \&$ Tipo $=\&$ Nombre $=$ Noticias. 
These two economic regimes commented on have guaranteed extremely high retributions far beyond the average market selling price (pool price). The regulated price has ranged between 6.8 and 10.9 times the mean market price from 2004 to 2008. As a result, over-cost has skyrocketed during this period because of the installed capacity boom explained above. It represented an $85.9 \%$ in 2008 and a $90.8 \%$ in 2007 of the retribution obtained by photovoltaic producers (Figure 6).

The spectacular increase in solar plant deployment has accentuated the 2008 rate deficit. However, it will do so even more intensely in 2009, at which point every plant that became operational in 2008 will by then have an entire year online, and also because many of them, operating under RD 661, will begin billing in 2009 (around $1222 \mathrm{MW}$, inferring from CNE estimates). For 2008, the mean sale price of electricity generated from solar photovoltaic power is 7 times higher than the mean price of the pool. ${ }^{38}$

Thus, the over-cost of photovoltaic production, which has to be somehow subsidized affecting the rate deficit, is and will continue to be enormous. The accumulated rate deficit from 2000 to 2008 is around 15,189 million Euros (based on provisional settlements published by CNE). Just in 2008, it has amounted to 5,640 million Euros (over a third of the total deficit). The estimated $500 \%$ growth in installed capacity in 2008 implies that the rate deficit could increase uncontrollably in coming years (Figure 7).

And after all of these economic efforts, solar energy failed even to reach 1\% of Spain's total electricity production in 2008.

\section{The looming collapse of the photovoltaic sector}

It is in this context that the Royal Decree 1578/2008 of September $26^{\text {th }}, 2008$ (whose results we will not be able to analyze for a few more months) becomes effective and sets forth a very restrictive and arduous regulation on the photovoltaic industry. First of

\footnotetext{
38 Electricity «market price» originated in the wholesale market.
} 
FIGURE 6

(A) AVERAGE SOLAR PRICE VS. AVERAGE POOL

PRICE PER KWH.

(B) TOTAL RETRIBUTION AND OVER-COST (MILL. €) OF SOLAR ENERGY (2004-2008)
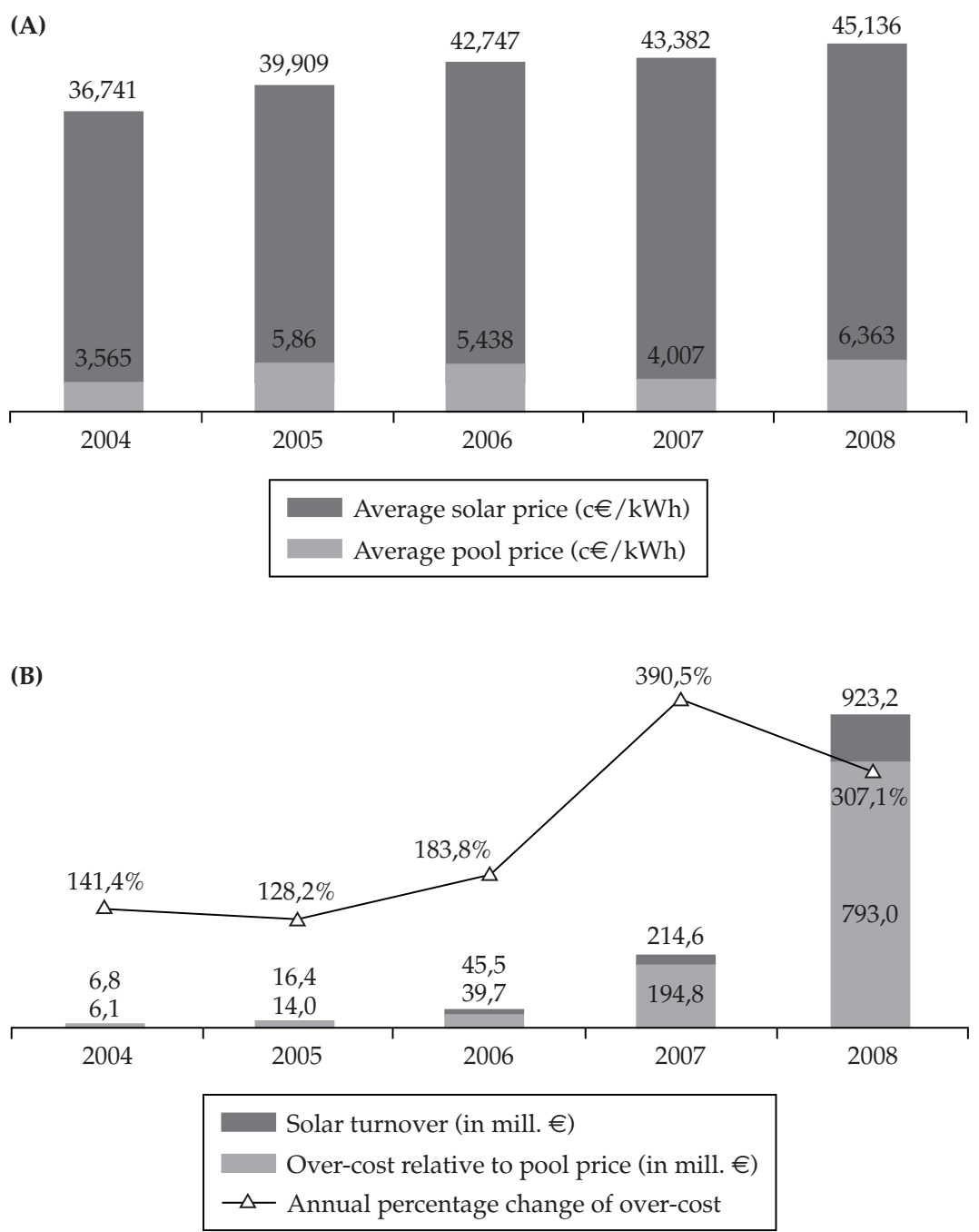

Source: CNE, own elaboration. 
FigURE 7

2000-2008 ANNUAL RATE DEFICIT (IN MILLIONS OF €)

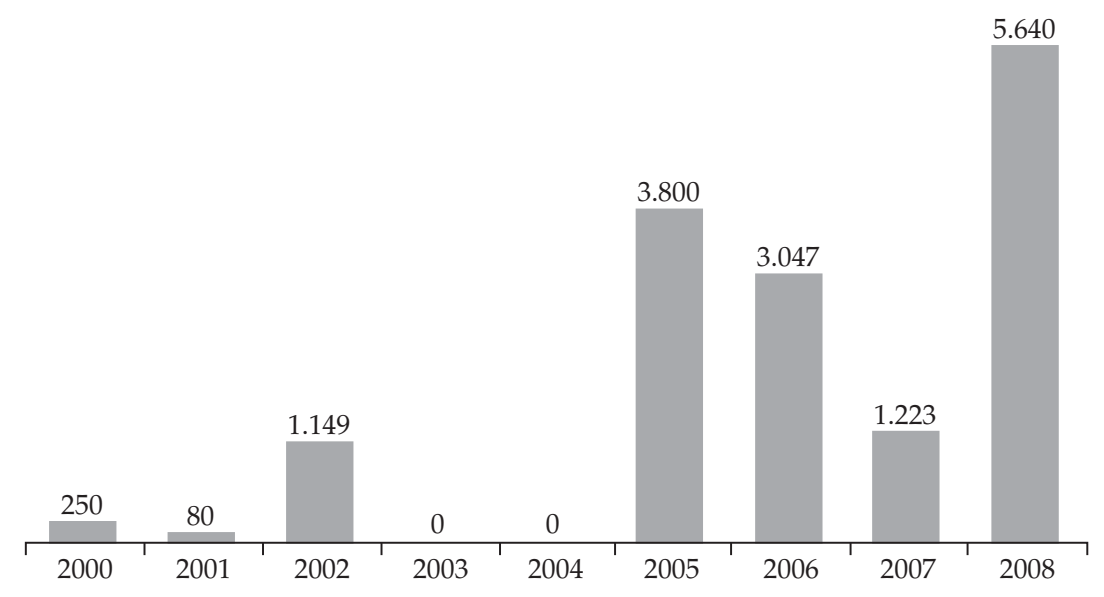

Source: From 2000 to 2007, based on the document «El déficit de tarifa», ${ }^{39}$ by «Energía y Sociedad». Rate deficit from 2008, source CNE: Settlement report for $2008^{40}$.

all, it will very much favor roof installations (on buildings) to the detriment of those on the ground because the recent «speculative» growth of photovoltaic has taken place in the latter form; fears of an increasing rate deficit has reined in a massive deployment of solar plants by producers foreign to the industry (according to the Ministry of Industry).

Secondly, it greatly decreases retributions to new installations, applying a reduction close to $30 \%$, which especially affects the ground photovoltaic industry (the most developed so far).

Finally, a quota system is implemented to monitor the expansion of the industry. In 2009, a maximum of $400 \mathrm{MW}$ of capacity will be the total allowed under the new regulated rates. To that amount, another $100 \mathrm{MW}$ are allowed to avoid a sudden deceleration in the industry (plants installed in 2009 beyond the 500 MW limit shall see their subsidy reduced). Furthermore, plants within the quota policy will be penalized.

\footnotetext{
39 Energía y Sociedad (2009).

40 CNE (2009b).
} 
As we can see, the industry faces a substantial chance at failing if we take into consideration that, according to data estimated by the CNE, only $3464 \mathrm{MW}$ have been installed in 2008. The Photovoltaic Industry Association (ASIF), in a press release of February $16^{\text {th }}, 2009$, estimates that there have been 15,000 job losses in the solar sector just a few months after RD $1578 / 2008$ has taken effect. ${ }^{41}$

This reflects the boom/bust nature of the renewables industries, or any others which exist and subsist solely due to subsidies, mandates and similar regimes, which have been experienced to great effect and which must not be ignored by any country claiming a desire to replicate Europe's experience.

\section{The expansion of renewable energy and its link to the expansion of credit}

The economic cycle has been the second factor helping the explosion of renewable energy in Spain.

The availability of low interest rates and easy credit that Spain enjoyed from 1998 until 2007 allowed credit-dependent industries to develop with great success. Renewable energy was not an exception and they witnessed an enormous increase in plant deployment during those years.

However, as the credit bubble ballooned and with it, an economic bonanza, the seeds of reversal and crisis were being planted.

The world begins to finally feel the credit crisis in the last half of 2007. From that point on, the other heavily leveraged industries collapse: real estate - a sector of notable overinvestment in Spain $^{42}$ - transportation, machinery, etc. Renewable energies,

41 ASIF (2009).

42 The residential houses started in Spain from 2004 to 2006 were 2,163,400 (Instituto Nacional de Estadística: «Estadísticas de la construcción»), on average more than 700,000 per year for a 45 million population. For comparative purposes, in the US, the number of started houses reached up to 1,716 millions in 2005 (US Census Bureau: «New residential construction»), which means the peak year of the real estate boom for 300 million people. In the US, comparing relative population, the equivalent of this overexpansion would be new residential houses started per year of 4,800,000. 
especially photovoltaics, however, remain one of the preferred outlets for credit concession during the past year-and-a-half. Thus, in 2007 and 2008, the growth of credit destined to the production and distribution of electric energy (and other utilities gas and water) skyrockets (see previous graph), while the rest of the productive sector of the economy diminishes its levels of leveraging in 2007 - more steeply by the second half, when signs appear that unequivocally show that the economic crisis has started in Spain and ceases leveraging completely in 2008 (Figure 8).

As we can see, the growth in photovoltaic power between the second half of 2007 and September of 2008 was enormous (up to several thousand MW according to either estimates or official date

FIGURE 8

EXPANSION IN CREDIT DESTINED TO FINANCE THE «PRODUCTION AND DISTRIBUTION OF ELECTRIC ENERGY, GAS AND WATER» AND THE REST OF PRODUCTIVE ACTIVITY FOR 2004-2008

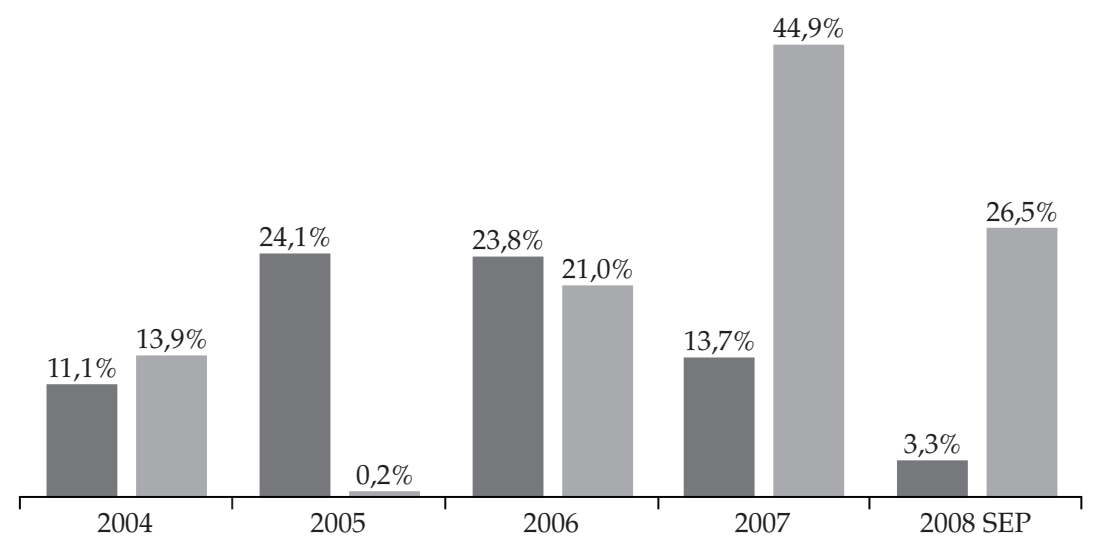

Rate of annual variation of credit for productive activities (without utilities) Rate of annual variation of credit for prod. and distr. of electric energy, gas

Note: As an approach to the credit assigned to renewable energy sources, we use the category measured by the Bank of Spain: «production and distribution of electric energy, water and gas».

Source: Statistical bulletin from the Bank of Spain. «Total créditos y total créditos dudosos a otros sectores residentes para financiar actividades productivas». 
from the $\mathrm{CNE}$ ). This was a result of economic distortions brought about by their industry being a creature of government regulation.

Starting in October, between a more damaging retributive framework for photovoltaics and a banking liquidity crisis, we can foresee the evaporation of credit to this and other renewable sources as well.

III

\section{JOB CREATION IN THE WIND, MINI-HYDROELECTRIC AND PHOTOVOLTAIC INDUSTRY}

Having studied the Spanish policy of public assistance to renewables and the development of that sector, we now estimate the job creation attributable to the assistance provided to said industry. The first problem that we face is that existing studies rely on sources that cannot be externally analyzed, such as interviews. Furthermore, those studies often include every contract as job creation when many of them, in fact the majority of them given that we are in an artificial bubble, are contracts for installation and manufacturing that would only be sustainable if we assume that the record rates of installing capacity during the last years were maintained. Thus, we will look at the installed power of the three main renewable electricity sources in Spain and estimate the related job creation according to the report of the Commission's Monitoring and Modeling Initiative on Targets for Renewable Energy (MITRE) project.

According to the latest version, at this writing, of the «Monthly Report on Energy Purchases from Special Regime» ${ }^{43}$ (Jan 2009), the official and approximate data for installed capacity in Spain is as follows:

- Wind farms: 14,836 MW officially; 15,617 MW estimate.

- Mini-hydroelectric under $50 \mathrm{MW}$ : 1,949 MW officially.

— Photovoltaic plants: 2,934 MW officially; 4,156 MW estimate.

43 «Total annual retribution received by producers of the special regime in Spain, by technology» (chart 1.1). 
Different criteria may be used to estimate the jobs created towards the installation of electric power in each one of the main sources of renewable production. After comparing the results according to the ratios (employment/MW) between projects produced to the Administration and commercial offerings by major developers and turnkey builders, the estimates from the IDAE (Instituto para la Diversificación y Ahorro de la Energía), ${ }^{44}$ and the estimates from MITRE, we opt to accept results from the latter, a European research group cited earlier.

The data used for MITRE's report for Spain assume a higher generation of jobs than revealed in the analyzed reports (which can be explained in part by the inclusion of indirect jobs included in the study financed by the European Commission), but lower than what are obtained by following the IDAE (which we have discarded for having overstated the amount of contracts that were actually formalized in the sector):

- Estimate of the number of jobs created in wind power: We follow the data published in MITRE's report with regard to the total number of jobs created by wind energy production through 2010, that is, when the objectives of the EU's plan for 2010 should be completed. With its 14,836 MW installed and 28,579 GWh produced by the end of 2008 Spain, according to the report published for Spain by the European Commission (EC) titled "Complying with the objectives and putting renewables to work. Country Report, Spain,» 45 would be «close to" attaining the objectives for 2020 according to MITRE (current policies scenario). The goals are set at 15,614 installed MW and 37,558 generated GWh, which means, according to its estimates, the creation of 15,000 direct and indirect jobs. We accept that figure (that includes direct and indirect jobs) for the purposes of this study.

- Estimate of the number of jobs created in mini-hydroelectric energy: According to the above-cited EC-financed report,

44 IDAE is a public «Institute for the Diversification and Saving of Energy», currently dependent on the Ministry of Industry, Tourism and Commerce.

45 MITRE (2003) This project is part of the Alterner Programme (Directorate General for Transport and Energy. European Commission). 
«Meeting the targets and putting renewables to work,» 46 Spain should have created 4,700 jobs between 2000 and 2010 in the mini-hydroelectric sector. With 1,949 MW installed and 4,203 GWh produced towards the end of 2008, it would be far from achieving the 2010 objectives under MITRE's most conservative scenario (current policies scenario), which goals are set at 3,011 installed MW and 9,926 generated GWh. For the purposes of this study, we are going to assume that the objective had been attained in 2008 and that 4,700 direct and indirect jobs had been created ${ }^{47}$ in $2000-2008$ by mini-hydroelectric energy production.

- Estimate of the number of jobs created in mini-hydroelectric energy: According to the most optimistic scenario (advanced renewable policy scenario) that MITRE manages for the photovoltaic industry, Spain, with 2,934 installed MW towards the end of 2008 and 2,065 produced GWh, would have achieved the 2020 goal of 1,818 installed MW but not the goal of 2,289 GWh produced. From the point of view of job creation, however, we will consider that those objectives had been accomplished and the number of jobs indicated in MITRE, 14,500 positions, have been created. ${ }^{48}$

\section{Premiums for the generation of electricity}

The current remunerative scheme for the energy produced under special regime establishes a premium over the marginal daily market price for each MWh produced by renewable energies, or a flat rate independent of the period of electricity generation. We have calculated the amount of the premiums that have been committed by the Spanish legislation (the subsidies NPV in 2008

\footnotetext{
46 MITRE (2003).

47 We are being very generous in accepting such high job creation figures in this field since only two thirds of MITRE's expected power capacity under the most conservative scenario has been reached.

48 Again, we are assuming a higher number of created jobs than in purity should be derived from the comparison between MITRE's Spanish Country Report and the actual development of the photovoltaic industry.
} 
have been calculated at $4 \%$ ) with the assumption that since December $31^{\text {st }}, 2008$, there have not been any additional plants constructed and related employment holds steady. 10,951 million Euros would have been committed on wind energy in 2008, 1,173 in small hydroelectric and 8,629 million for photovoltaic generation (Table 2).

The above table shows the total over-cost that has been incurred from 2000 to 2008, calculating its net present value (NPV) at a $4 \%$ discount rate in 2008, which amounts to 7,918.54 million Euros.

\section{Investment}

To calculate the cost of investment in each of these sources we have used the standard cost for each one of these types of turnkey projects in the current market and applied it to the megawatt capacity installed between 2000 and 2008. Theoretically speaking, we are dealing with the replacement value of these projects according to the current state of the art.

— Wind projects: $1.1 \mathrm{M} € / \mathrm{MW} .{ }^{49}$

- Photovoltaic projects: $5.5 \mathrm{M} € / \mathrm{MW} .{ }^{50}$

— Mini-hydroelectric projects: $1.71 \mathrm{M} € / \mathrm{MW}^{51}$ (average).

In Table 3 we summarize the results achieved in terms of employment, subsidies and investment in the three main renewable industries. Since 2000, the renewable subsidies have created less

\footnotetext{
49 ICE (2002).

50 ASIF/APPA (2007). This is a conservative figure for turnkey projects because, for those installing two-axis solar tracking structure, prices revolve around 6.3 $\mathrm{M} € / \mathrm{MW}$ and around $5.2 € / \mathrm{MW}$ for fixed structure.

51 Average cost calculated from the annual average operation of mini-hydroelectric Spanish plants in the past 8 years $(2,556$ hours $)$ and considering that Spain, towards 31 December 2008 had 1,949 installed MW in 936 different locations. These figures bring about an average size per plant of 2.06MW, with an average installation cost between 1.45 M€/MW and 1.97 M€/MW, i.e., 1.71 M€/MW (average). This is the value that will be applied to the 624 installed MW from 2000 to 2008 . See "Checklist para inversión y estudios de viabilidad en Mini hidráulica», report published by the European Commission.
} 


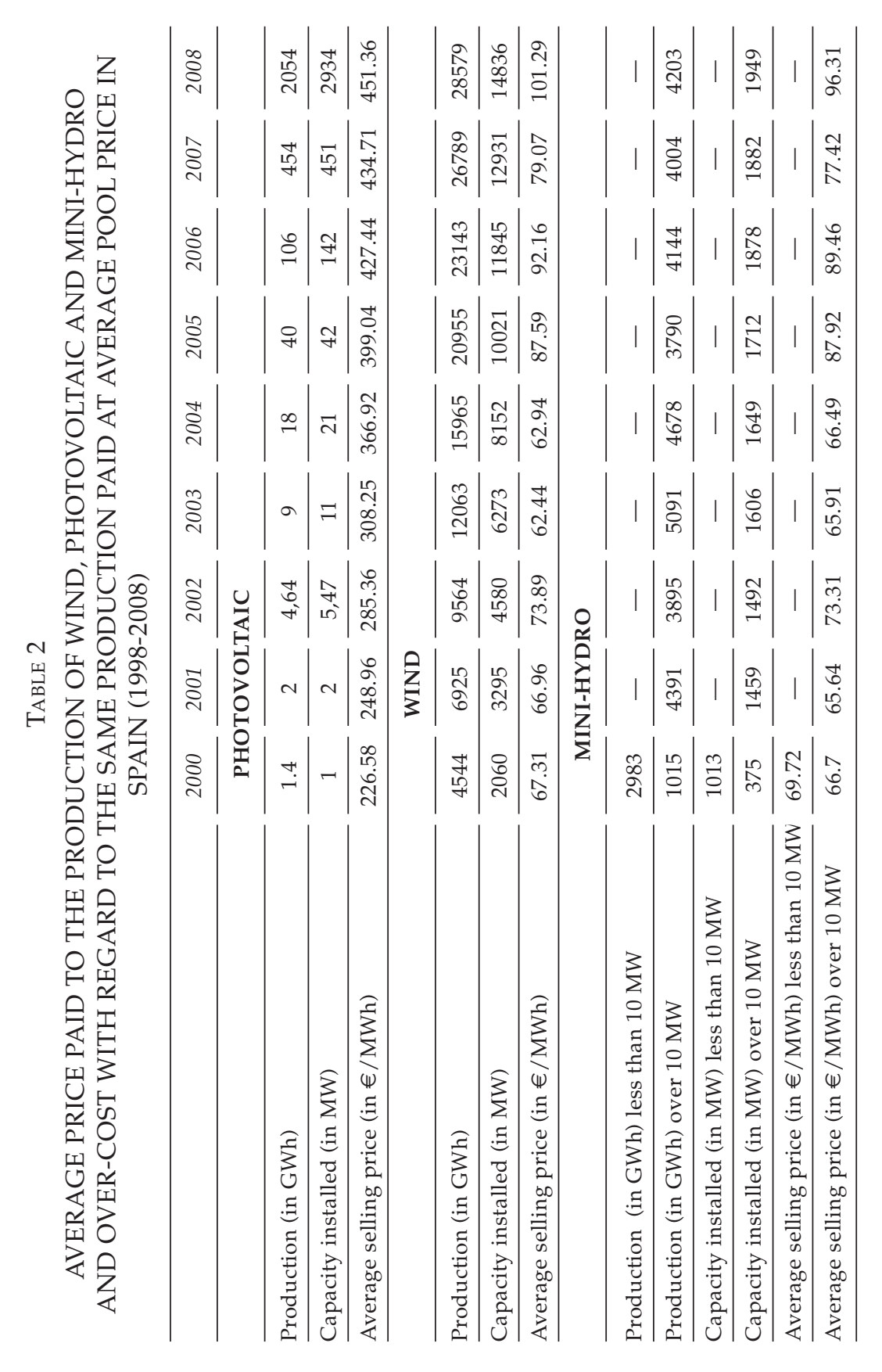




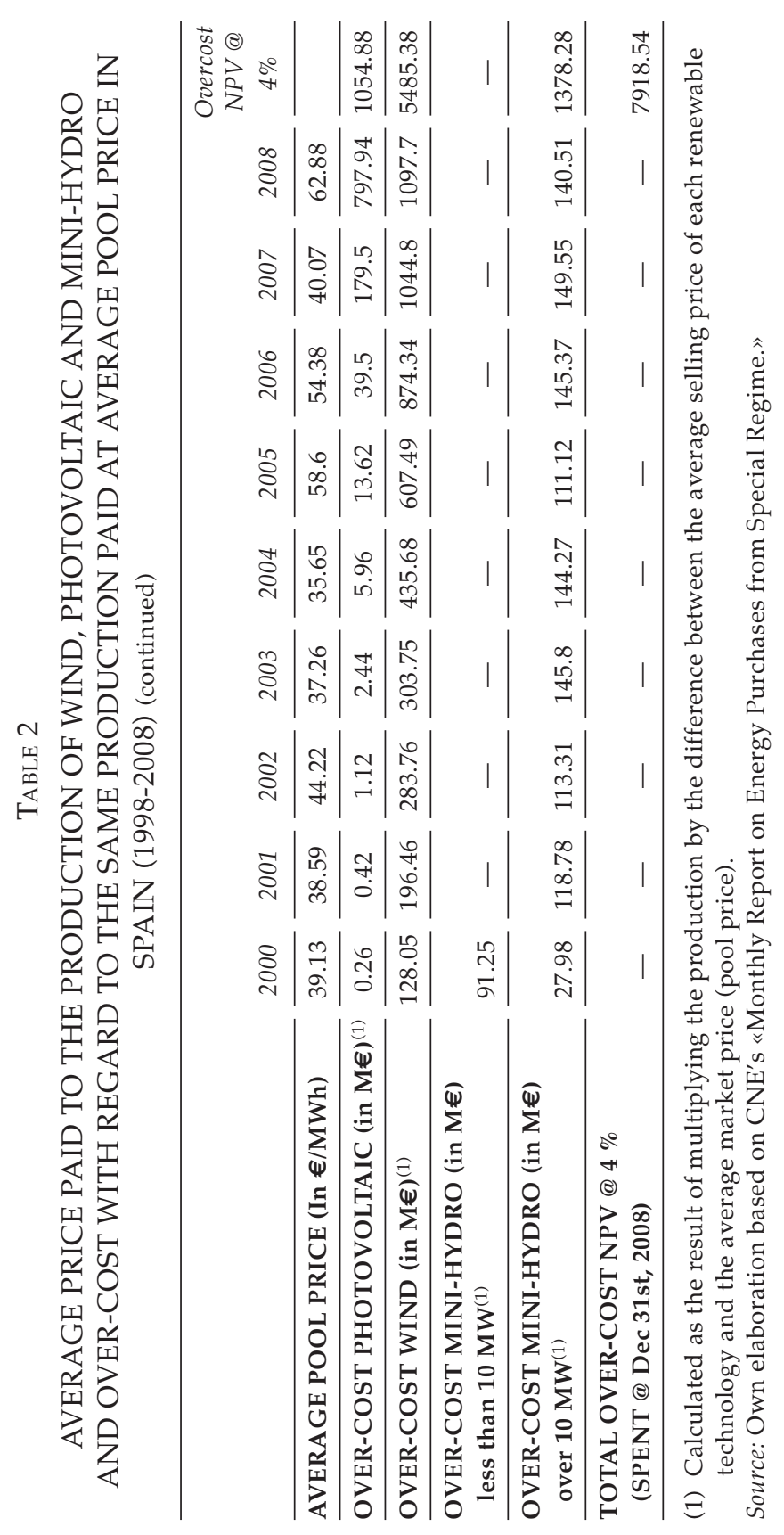




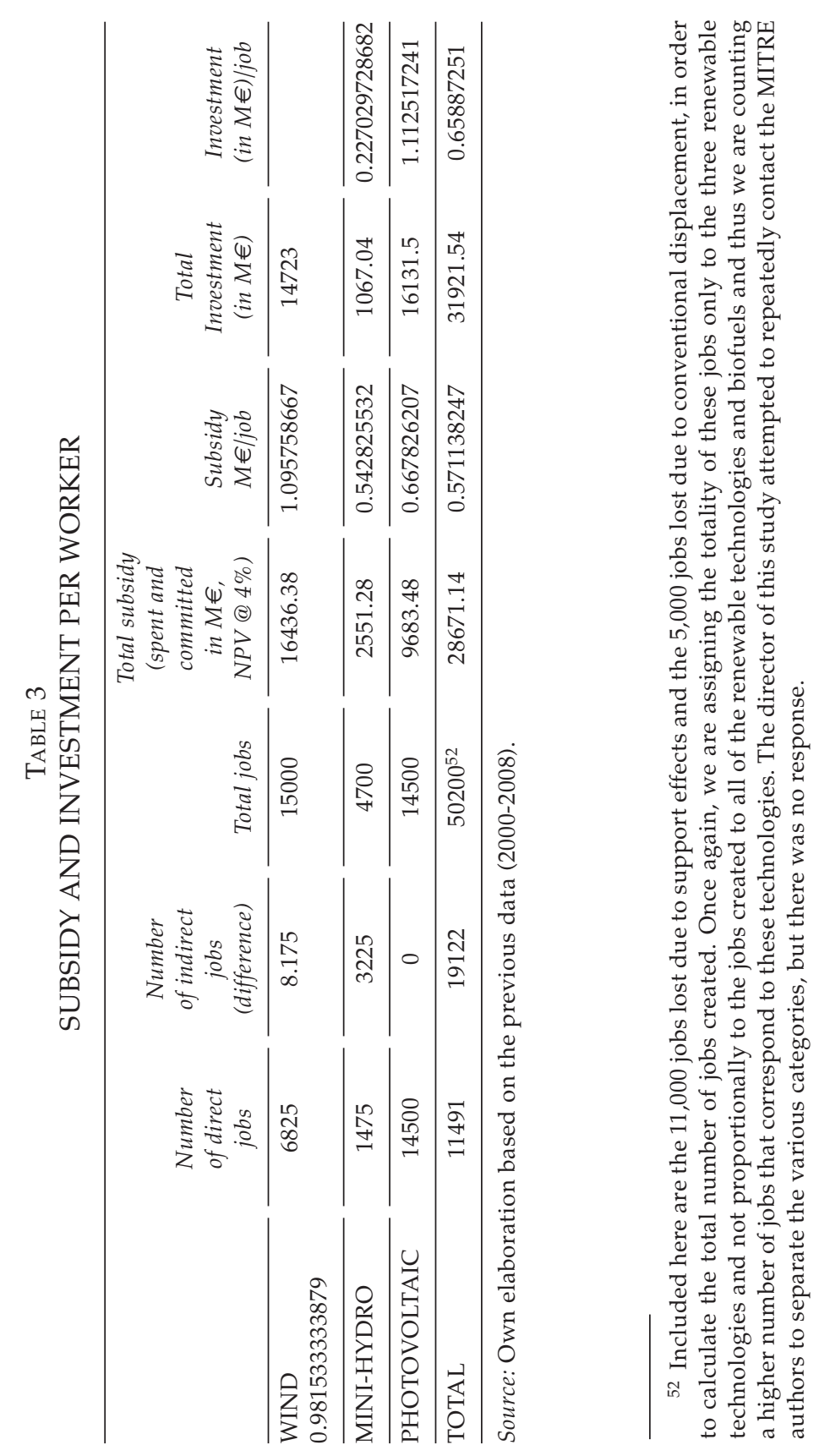


than 50,200 jobs. ${ }^{53}$ This amounts to $0.2 \%$ of Spain's workforce and $0.25 \%$ of Spain's employed workforce. We can see that the average subsidy per worker added in these three sources of renewable energies is more than half a million Euros $(€ 571,138)$, ranging from $€ 542,825$ per worker added in or by the mini-hydro sector and two-thirds of a million Euros per worker added in or by the photovoltaic sector, to well over $€ 1$ million per worker added in or by the wind industry.

\section{IV \\ A CALCULATION OF THE COST OF GREEN JOBS ON THE REST OF THE PRODUCTIVE ACTIVITY}

Public investment in renewable energy has job creation as one of its explicit goals, which, given the current economic crisis, suggests an intention of seeding a future recovery with "green job» subsidies. The problem with this plan is that the resources used to create "green jobs» must be obtained from elsewhere in the economy. Therefore, this type of policy tends to create not just a crowding-out effect but also a net destruction of capital insofar as the investment necessary must be subsidized to a great extent and this is carried out by absorbing or destroying capital from the rest of the economy.

The money spent by the government cannot, once committed to "green jobs», be consumed or invested by private parties and therefore the jobs that would depend on such consumption and investment will disappear or not be created.

Investment in green jobs will only prove convenient if the expense by the public sector is more efficient at generating wealth than the private sector. This would only be possible if public

53 According to Instituto Sindical de Trabajo, Ambiente y Salud (ISTAS), the distribution of those green jobs is the following: $9.58 \%$ are jobs in maintenance and operation, $24 \%$ are jobs in administration, marketing and projects and $66.27 \%$ in construction, fabrication and installation. At this point has to be stated that it is a usual practice to include the complete productive chain of renewable production of electricity and compare the figures with the jobs created by the energy sector just at the energy companies. AEE $(2008,33)$. 
investment were able to be self-financing without having to resort to subsidies, i.e., without needing to absorb wealth generated by the rest of the economy in order to support a production that cannot be justified through the incurred incomes and costs. We have calculated that the total public subsidy in Spain, both spent and committed, totals 28,671 million Euros (€28.7 billion or appx. $\$ 37$ billion USD), and sustains 50,200 jobs.

In order to know how many net jobs are destroyed by a green job program for each one that it is intended to create, we use two different methods: with the first, we compare the average amount of capital destruction (the subsidized part of the investment) necessary to create a green job against the average amount of capital that a job requires in the private sector; with the second, we compare the average annual productivity that the subsidy to each green job would have contributed to the economy had it not been consumed in such a way, with the average productivity of labor in the private sector that allows workers to remain employed.

\section{Stock of capital per worker}

The total amount of invested and promised money to guarantee the viability of renewable energy in Spain is as high as 28,671 million Euros, and, if we include the non-subsidized investment, up to 50,200 employees have been put to work.

This forcible loss of resources incurred by renewable energy programs must be compared with the average resources per worker allocated in the private sector. The parameter that most closely approximates it is the average stock of capital per worker, whose mean between 1995 and 2005 in Spain was 259,143 Euros.

Therefore, for every green job that is attempted to be created, there is a 2.2 destruction of the resources that on average the private sector employs per worker

$$
\frac{\text { Subsidy to renewables per worker }}{\text { Average capital per worker }}=\frac{571,138}{259,143}=2,2
$$


This is to say that for every renewable energy job that the State manages to finance, we can be confident that on average 2.2 jobs will be destroyed, to which we have to add those jobs that the non-subsidized investment would have created.

\section{The annual productivity of the expense}

In this section, we shall compare the average annual productivity that the green job subsidy would have contributed to the economy had it not been consumed in public financing, with the average productivity in the private sector that allows them to keep their job, the latter being ultimately the measure which justifies the creation or preservation of that job.

In order to obtain the annual public consumption of resources devoted to renewable energy we calculate the average annuity value during the next 25 years of subsidies. Now, what should be the rate at which we discount the annuities? In a private enterprise, the adequate rate would be the ROA (return on assets) because this is the rate of additional return that we would have obtained over a year if we had allocated, in the private sector, the annual cost of renewables.

For an entire economy, the closest thing we have to an ROA is the relationship between the annual income of capital and the stock of capital in the economy, that is, a ratio of the annual return on that stock of capital.

In Spain, annual capital profitability has slowed in recent years and thus we will take the lowest rate available: $8.53 \%$ in $2005 .{ }^{54}$ With this discount, the average annuity for the end of 2008 is $€ 55,946$ per worker.

This figure must be compared with the annual average productivity per worker in the rest of the economy. We can obtain this data by dividing the total income of labor in the economy by the number of workers. Thus, the average productivity per worker, between 2003 and 2007, was 25,332 Euros. ${ }^{55}$

${ }^{54}$ Own elaboration from National Accounting figures published by National Statistics Institute (INE) and the BBVA Research Foundation.

${ }^{55}$ Cuentas Nacionales, INE. 
Thus, on average, the subsidized green job destroys the resources required to have created 2.2 jobs in the economy.

$$
\frac{\text { Annual subsidy to renewables per worker }}{\text { Average productivity per worker }}=\frac{55,946}{25,332}=2,2
$$

Consequently, through the use of both methods we have reached a similar conclusion: for every green job, we can be highly confident that 2.2 jobs are destroyed elsewhere in the economy, to which we have to add those jobs that the nonsubsidized investment would have created.

With that said, not all forms of energy sources are equally destructive, given that, to remain competitive, not all of them require the same amount of subsidy per megawatt. Our calculations, charted, reveal the following (Figure 9).

We see that solar energy is significantly less competitive given that it requires more than twice the amount production of subsidy

FIGURE 9

SUBSIDY PER MW (IN €)

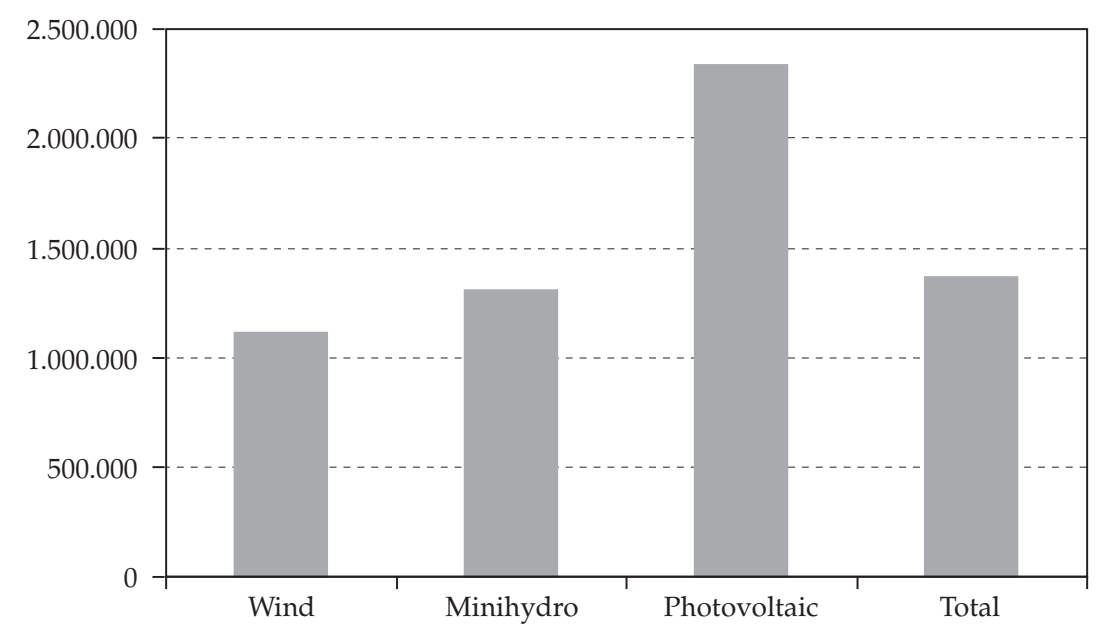

Source: Own elaboration. 
per megawatt compared to wind energy. By putting the per megawatt subsidy data in relation to the mean amount of capital resources, we obtain the number of jobs lost as a result of each kind of subsidized renewable energy source.

We achieve an identical result by relating the present value of an annuity of the sum of the committed amount with the annual productivity of labor:

As we can see in Figure 10, each renewable megawatt installed, on average (given Spain's breakdown of individual source contributions), destroys 5.28 jobs, compared with the 4.27 jobs destroyed per megawatt of wind energy, the 5.05 jobs destroyed per megawatt of mini-hydro and the 8.99 destroyed per megawatt of photovoltaic installed capacity as a result of «green jobs» mandates, subsidies and related regimes.

This result is important, since although solar energy may on paper appear to employ many workers (essentially in the plant's construction), the reality is that for the plant to work, it requires consumption of great amounts of capital that would have instead

FIGURE 10

EMPLOYMENT DESTROYED PER INSTALLED MEGAWATT

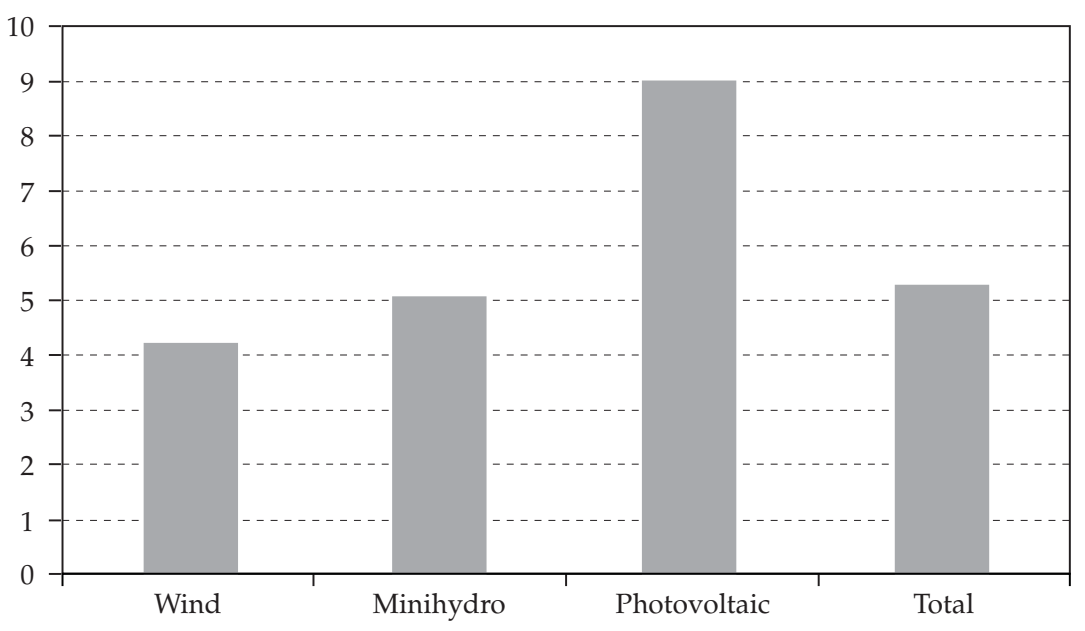

Source: Own elaboration. 
created many more jobs in other parts of the economy. Inversely, wind power, while still noxious in its economic impact when coercively introduced through state intervention, wastes far fewer resources per megawatt of installed capacity and thus does not destroy as many jobs in the rest of the economy.

This case is similar to the one that French economist Frédéric Bastiat denounced in his famous «Petition by the candle-makers,» in which he ridicules the intentions of protectionist entrepreneurs by comparing them to candle-makers clamoring for the state to crowd-out the sun, which was competing with them unfairly when providing light. In their opinion, if the sun was barred from providing light, numerous jobs would be created in the candle manufacturing industry. Obviously, this is not so: precisely by not being able to profit from the sun's light we would be wasting scarce resources in the production of candles instead of producing other goods and services that would increase our wealth.

Finally, it is worth considering the distribution of the destroyed jobs across the economy. Obviously, the specific productive sectors affected will depend on how the government finances the subsidies to renewable energy. We can basically separate the approaches intro three groups: increases in energy rates, increase in taxes or an increase in public debt.

The first method aims to correct the rate deficit, which in part is caused by the subsidies to the renewables, evidenced by a higher future electric cost. According to the National Energy Commission, the price of a comprehensive energy rate (paid by the end consumer) in Spain would have to be increased 31\% to begin to repay the historic debt generated by this deficit. ${ }^{56}$

It is obvious that, if the rates were to increase by $31 \%$ - or by a lower percentage which, while it would not eliminate the deficit, it would reduce it - the energy intensive companies would suffer a very pronounced decline in their profitability and would have to reduce or eliminate operations in Spain. In our country, the sectors that consume the most energy are metallurgy, non-metallic mining and food processing, beverage and tobacco (Figure 11).

56 CNE (2008). 
FiguRE 11

ELECTRICITY CONSUMPTION (IN MILLIONS OF €)

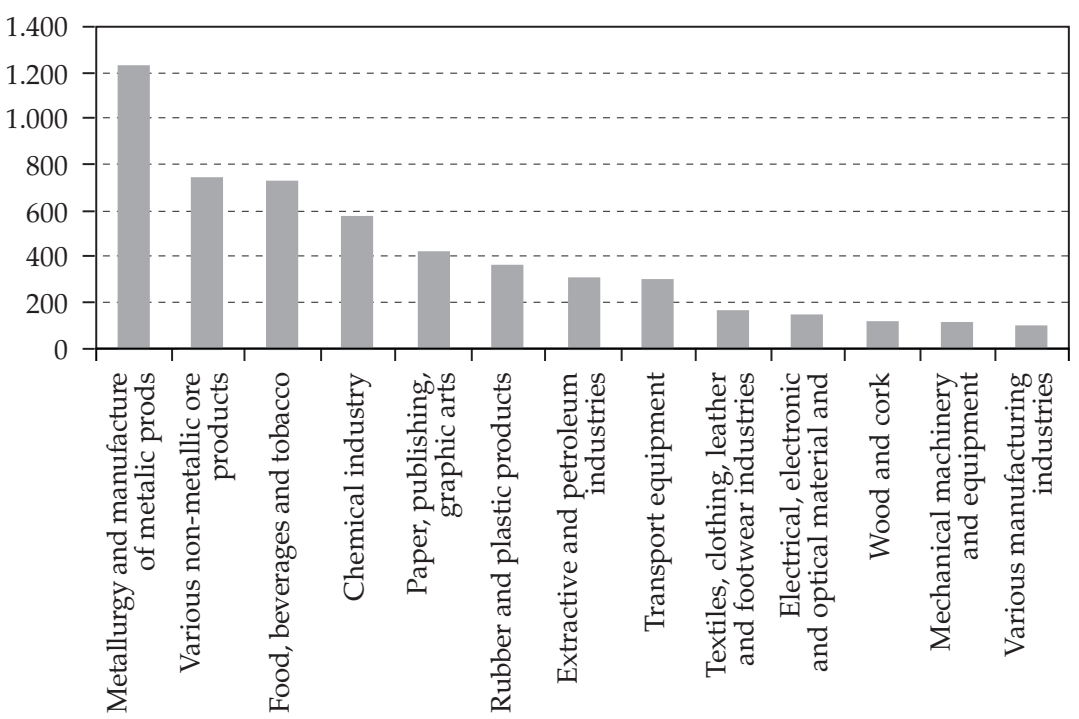

Source: INE (National Statistics Institute). From the Energy consumption survey (2007), table «Energy consumption by groups of activity and product consumed.» (In this figure, the product shown is electricity).

From the groups above, it is worth highlighting that some of the most affected industries ${ }^{57}$ would be producers of basic iron and steel products (in Spain, it consumed $€ 470.77$ million), basic chemical products (€382.13 million), plastics (€297.18 million), manufacture and first transformation of precious metals ( $€ 280.58$ million) as well as producers of cement, lime and plaster (€202.22 million).

Unsurprisingly, the steel mills, the most electricity-intensive sector, have already been hurt by the high prices of electricity in Spain, exactly as the Acerinox example discussed below.

It is possible, of course, as it is indeed the case today in Spain, that the administration may try to prevent the most energy-intensive

57 Source: the most electricity-intensive industries pointed out here are taken from INE's Energy consumption survey (2007), table «Energy consumption by activity sectors and product consumed». 
companies from leaving by bestowing upon them the privilege of paying a lower rate than the rest of the consumers pay. In Spain, it happens with the G4 rate, which is being taken advantage of by companies such as Arcelor Mittal, Asturiana de Zinc and Alcoa. But, as we have said, this privilege exacerbates the rate deficit, which, ultimately, must be financed through higher prices for the rest of non-privileged consumers or for the taxpayer.

And this leads us to the second possibility that we will mention to finance the rate deficit: an increase in taxation.

This method reduces the amount of income that consumers or businesses have available, reducing consumption and/or investment. For example, the average annuity payable to renewables is equivalent to $4.35 \%$ of all VAT collected, $3.45 \%$ of the household income tax, or $5.6 \%$ of the corporate income tax for $2007 .{ }^{58}$ Regardless of whether the increase impacts consumption or investment more, the most affected sectors of the economy will be those with a greater pro-cyclical productions (such as automotive).

Finally, the subsidy to pay for "green jobs» or renewables could be financed by issuing public debt. This strategy poses a similar effect to the previous method but spread out over time (since it implies higher future taxes). However, debt has an additional effect: a restriction of present available credit that a business could use to refinance its debt or undertake new investments. Thus, employees of the most leveraged businesses or of investment projects that would need cheaper credit to be undertaken will suffer the costs of the renewables.

It is not possible to directly translate Spain's experience with similar exactitude or confidence, and claim that the U.S. should expect a loss of from 6.6 million to eleven million jobs as a direct consequence were the promise to create 3 to 5 million «green jobs» met (in addition to the jobs lost due to the opportunity cost of private capital employed in renewable energy), although the study clearly reveals that if President Obama would dedicate the massive resources needed to create those 3 to 5 million jobs, the U.S. should certainly expect its results to follow such a tendency.

\footnotetext{
58 Own elaboration from Eurostat figures.
} 
At minimum, therefore, the study exposing the Spanish experience that President Obama cites as a model for the U.S. to replicate in quickly implementing "green jobs» programs serves as a note of caution: the reality is far from what has typically been presented, and such schemes offer considerable employment consequences and implications for the economic crisis.

\section{Spain's self-inflicted economic wounds from «Green Jobs» regimes}

The late 90s already witnessed an energy leakage in Spain. As Jesús Lizcano Álvarez, professor of Accounting and Financial Economics at Universidad Autónoma de Madrid, put it, «Other substantial costs that can determine in some industries whether a relocation decision takes place can be energy costs, which - since they are higher in Spain than elsewhere nearby - along with other factors, have been crucial in cases such as the one of the Chemical company Hoeschst Ibérica, in its redirection of part of its investments abroad, or the case of Marcial Uchin, when deciding to build a steel mill in France, where energy costs are clearly competitive compared to Spain's.» ${ }^{59}$ Companies such as Sidenor have followed a similar path moving electric ovens to, e.g., France and other countries outside the EU, where energy prices are more competitive in the global market.

In April of 2004, the Mining-Metalurgy Federation of CC.OO. strongly denounced the decision by the Grupo Celsa (parent company of Trefilerías Quijano, Global Steel Wire, Tycsa PSC, Tycsa Servicios, Laminaciones Arregui, Nervacero, Trefilerías Moreda, Celsa y Riviere) to close Trefilerías Quijano which, according to this union organization, was obeying a relocation policy as part of a plan to purchase a factory in Poland. However, the same union organization acknowledged the true culprit of these relocations when, in 2008, they warned that «we must take into account the profound impact that» an increase in energy costs

\footnotetext{
59 Lizcaíno Álvarez (1995).
} 
"would have on the overall economy, and specifically, on industry and employment and families.» The union perhaps would have obtained better results had they protested the European energy policy responsible for the loss of competitiveness in this sector, which has been zealously put into practice by the Spanish government.

Towards the end of 2006, UNESID (Unión de Empresas Siderúrgicas) warned that the process of liberalizing the electric market would lead to a relocation of a good portion of this industry due to the loss of competitiveness caused by high energy costs in Spain due to an energy policy closely linked to the promotion of renewable energy.

That same year, Ferroatlántica sounded the alarm. The company, the only producer of iron alloys in Spain, had an electric consumption of 2,300 Ghw in 2006 on Spanish soil and is the economic engine of the region of A Costa da Morte (Galicia). The continual increase in the cost of energy studied in this paper caused a change in the percentage of energy as a total cost of production in ferrosilicium from $37.1 \%$ in 1997 to $38.6 \%$ in 2000 and $43.2 \%$ in 2005 . After years of installing efficient energy management measures, and increasing its productivity, in 2006 Ferroatlántica's factories had reached their productive capacity.

Because of that reality, the increases in energy prices had caused Ferroatlántica to lose competitiveness. The closing of the plants and their relocation to other countries such as France, where they already had a presence, is - according to the company unstoppable.

The company stated that the challenge is clear: "only internationally competitive energy prices will allow us to support such a basic industry, not only because it belongs to a strategic sector, but also to support employment and generate wealth.»

Gonzalo Urquijo, president of UNESID, has repeatedly shown his and the industry's concern about energy prices in Spain. In 2007, he denounced, before the Minister of Industry, that the electric rates had gone up 30\% in two years, not to mention an increase of $85 \%$ in the price of natural gas. Urquijo remarked that «though the increase in prices has been absorbed in the last two 
years due to the strength of the demand, when consumption lowers this sector will find that the increase in prices has become permanent causing an unfavorable impact on its competitiveness.» This is precisely what is happening in Spain, presently, where the metallurgy industry is facing its biggest loss in demand in its history.

Facing a grave situation, 18 energy intensive Spanish companies, representing sectors such as metallurgy, cement, chemicals, ceramics and gas, and operating more than 100 factories, formed in September of 2007 an association to attempt to lower the elevated price they pay for electricity and thus be able to compete with companies in other countries where the electric cost is not as cumbersome. These companies comprise $18 \%$ of the industrial electric consumption in Spain and 7\% of the total demand in the Iberian Peninsula.

The goal of this union is twofold. On the one hand, it is to act as a central energy purchaser and, on the other, to attempt to receive from the administration special treatment allowing them to be exempted from paying the invoice incurred by the current energy policy. If they fail at this, shutting down and fleeing abroad will be unavoidable. The president of Asturiana de Zinc (one of Fortia's members), Santiago Zaldumbide, has openly declared that his company will relocate if no alternative is found to paying such a high market price of electricity in Spain. In terms of labor costs, what is at risk if these 18 companies relocate are the 47,000 jobs that they currently mantain.

Before liberalizing the purchase of electricity by large consumers in July of 2008, the high-voltage regulated electric rate had been continually increasing, pushed by the burgeoning costs of electricity generation. Thus, between 1998 and 2008, the highvoltage rate increased by $40 \%$. Last year, due to the change in rate, the large electricity consumers saw their electric price go up near $55 \%$.

Further, the AEGE (Asociación de Empresas con Gran Consumo de Energía) has for some time warned about the same risks caused by Spain's energy policy. Its vice president, Javier Penacho, pointed out in May of 2008 that in a system such as the current one, «the reference price of energy is determined by the 
worst technology available on the market» and that this would «have grave consequences in matters of competitiveness, relocations and de-investments.»

But perhaps the most telling example of the effects that we are studying, given its size, situation as a global enterprise, its Spanish origin and flexibility in managing its plants in 3 continents (and 4 soon), is that of the world's second-largest manufacturer of stainless steel, Acerinox.

Acerinox has already reduced or avoided extending its presence in Spain due to the high energy costs. Victoriano Muñoz, who led that company for 37 years, warned of the dangers of an electricity market distorted by such interventions in Spain as it would impose higher energy costs for industry. In April of 2002 he explained that the price of electricity for consumers had increased by $10.6 \%$ since the beginning of the decade, not to mention the related dozens of interruptions in the provision of that service.

A year later, the president of this leading stainless steel producer explained that in spite of good management and profits, important doubts had been cast about the company's operations as a result of the Kyoto agenda - a key part of which is a similar "green jobs» push - leading to possible relocation due to higher energy costs to nations that do not impose such regimes.

Consequently, when in 2004 Acerinox decided to increase the size and capacity of its operations it did so at plants in Kentucky (USA) and Columbia (South Africa), deciding to freeze its expansion plans in Spain, it cited the energy cost factor as influential. Consequently, green energy was to blame for the export of growth, meaning the transfer of hundreds of jobs from Spain to the USA and to South Africa.

In his last press appearance as CEO of Acerinox in July of 2008, Muñoz expressed regret and concern over the loss of competitiveness in the Spanish industry, which he blamed primarily on the continuous increase in energy prices. «We are going to have the highest prices in Europe,» he said during his farewell, in which he once again urged removal of the barriers to construct nuclear plants as a way to achieve the Kyoto 
objectives, instead of the emphasis on renewable energy regimes that increase the price of electricity but not its reliability.

That final meeting with the press took place after Muñoz's last general shareholder meeting as president of Acerinox. In his remarks, he spoke of the loss of competitiveness in the Spanish industry due to a new 9.2\% rise in actual cost per Kwh in 2006, the latest of many previous increases. However, this businessman, famous for his entrepreneurial spirit, commented that «we are afraid that the worst is yet to come,» because, beyond the changes in regulated rates, «the continuous reduction of the hydroelectric and nuclear energy production share of the total Spanish electrical system.»

Victoriano Muñoz associated Spain's ever-higher energy prices with the "green energy» policies enacted as a result of the Kyoto Protocol, even more than the «cap-and-trade» policy also adopted under Kyoto. Indeed, he explained that, although capand-trade had not yet directly harmed their bottom line, «indirectly, it affects [operations] very negatively through higher energy cost.» ${ }^{60}$ That is, cap-and-trade's impact was first felt in the form of programs escalated in anticipation of the regime's implementation, in that cap-and-trade's goals spurred further «green jobs» schemes and deployment of renewable energy, the principal factor in the energy price spikes harming energyintensive producers.

\section{$\mathrm{V}$ \\ CONCLUSIONS}

Europe's current policy and strategy for supporting the so-called «green jobs» or renewable energy dates back to 1997, and has become one of the principal justifications for U.S. «green jobs»

60 Mr. Muñoz statements at Acerinox's annual reports and speeches at the General Shareholder Meetings (2002-2007) are downloadable at www.acerinox.es. His last press conference, that can be found at the following link: http:// www.eleconomista.es/empresas-finanzas/noticias/229443/06/07/Acerinox-estaestudiando-proyecto-en-India-con-japonesa-Nisshin-Steel-II.html. 
proposals. Yet an examination of Europe's experience reveals these policies to be terribly economically counterproductive.

This study is important for several reasons. First is that the Spanish experience is considered a leading example to be followed by many policy advocates and politicians. This study marks the very first time a critical analysis of the actual performance and impact has been made. Most important, it demonstrates that the Spanish/EU-style «green jobs» agenda now being promoted in the U.S. in fact destroys jobs, detailing this in terms of jobs destroyed per job created and the net destruction per installed MW.

The study's results demonstrate how such «green jobs» policy clearly hinders Spain's way out of the current economic crisis, even while U.S. politicians insist that rushing into such a scheme will ease their own emergence from the turmoil.

The following are key points from the study:

1. As President Obama correctly remarked, Spain provides a reference for the establishment of government aid to renewable energy. No other country has given such broad support to the construction and production of electricity through renewable sources. The arguments for Spain's and Europe's "green jobs» schemes are the same arguments now made in the U.S., principally that massive public support would produce large numbers of green jobs. The question that this paper answers is «at what price?»

2. Optimistically treating European Commission partially funded data, ${ }^{61}$ we find that for every renewable energy job that the State manages to finance, Spain's experience cited by President Obama as a model reveals with high confidence, by two different methods, that the U.S. should expect a loss of at least 2.2 jobs on average, or about 9 jobs lost for every 4 created, to which we have to add those jobs that non-subsidized investments with the same resources would have created.

3. Therefore, while it is not possible to directly translate Spain's experience with exactitude to claim that the U.S. would lose

61 The MITRE project was partially funded by DG TREN (Energy \& Transport) of the European Commission under the Altener programme. 
at least 6.6 million to 11 million jobs, as a direct consequence were it to actually create 3 to 5 million «green jobs» as promised (in addition to the jobs lost due to the opportunity cost of private capital employed in renewable energy), the study clearly reveals the tendency that the U.S. should expect such an outcome.

4. At minimum, therefore, the study's evaluation of the Spanish model cited as one for the U.S. to replicate in quick pursuit of "green jobs» serves a note of caution, that the reality is far from what has typically been presented, and that such schemes also offer considerable employment consequences and implications for emerging from the economic crisis.

5. Despite its hyper-aggressive (expensive and extensive) «green jobs» policies it appears that Spain likely has created a surprisingly low number of jobs, two-thirds of which came in construction, fabrication and installation, one quarter in administrative positions, marketing and projects engineering, and just one out of ten jobs has been created at the more permanent level of actual operation and maintenance of the renewable sources of electricity.

6. This came at great financial cost as well as cost in terms of jobs destroyed elsewhere in the economy.

7. The study calculates that since 2000 Spain spent $€ 571,138$ to create each "green job», including subsidies of more than $€ 1$ million per wind industry job.

8. The study calculates that the programs creating those jobs also resulted in the destruction of nearly 110,500 jobs elsewhere in the economy, or 2.2 jobs destroyed for every «green job» created.

9. Principally, the high cost of electricity affects costs of production and employment levels in metallurgy, non-metallic mining and food processing, beverage and tobacco industries.

10. Each «green» megawatt installed destroys 5.28 jobs on average elsewhere in the economy: 8.99 by photovoltaics, 4.27 by wind energy, 5.05 by mini-hydro.

11. These costs do not appear to be unique to Spain's approach but instead are largely inherent in schemes to promote renewable energy sources. 
12. The total over-cost - the amount paid over the cost that would result from buying the electricity generated by the renewable power plants at the market price - that has been incurred from 2000 to 2008 (adjusting by $4 \%$ and calculating its net present value [NPV] in 2008), amounts to 7,918.54 million Euros (appx. \$10 billion USD).

13. The total subsidy spent and committed (NPV adjusted by $4 \%$ ) to these three renewable sources amounts to 28,671 million euros (\$36 billion USD).

14. The price of a comprehensive electricity rate (paid by the end consumer) in Spain would have to be increased 31\% to being able to repay the historic debt generated by this rate deficit mainly produced by the subsidies to renewables, according to Spain's energy regulator.

15. Spanish citizens must therefore cope with either an increase of electricity rates or increased taxes (and public deficit), as will the U.S. if it follows Spain's model.

16. The high cost of electricity due to the green job policy tends to drive the relatively most electricity-intensive companies and industries away, seeking areas where costs are lower. The example of Acerinox is just such a case.

17. The study offers a caution against a certain form of green energy mandate. Minimum guaranteed prices generate surpluses that are difficult to manage. In Spain's case, the minimum electricity prices for renewable-generated electricity, far above market prices, wasted a vast amount of capital that could have been otherwise economically allocated in other sectors. Arbitrary, state-established price systems inherent in "green energy» schemes leave the subsidized renewable industry hanging by a very weak thread and, it appears, doomed to dramatic adjustments that will include massive unemployment, loss of capital, dismantlement of productive facilities and perpetuation of inefficient ones.

18. These schemes create serious «bubble» potential, as Spain is now discovering. The most paradigmatic bubble case can be found in the photovoltaic industry. Even with subsidy schemes leaving the mean sale price of electricity generated from solar photovoltaic power 7 times higher than the mean 
price of the pool, solar failed even to reach $1 \%$ of Spain's total electricity production in 2008.

19. The energy future has been jeopardized by the current state of wind or photovoltaic technology (more expensive and less efficient than conventional energy sources). These policies will leave Spain saddled with and further artificially perpetuating obsolete fixed assets, far less productive than cutting-edge technologies, the soaring rates for which soon-to-be obsolete assets the government has committed to maintain at high levels during their lifetime.

20. The regulator should consider whether citizens and companies need expensive and inefficient energy - a factor of production usable in virtually every human project - or affordable energy to help overcome the economic crisis instead.

21. The Spanish system also jeopardizes conventional electricity facilities, which are the first to deal with the electricity tariff deficit that the State owes them.

22. Renewable technologies remained the beneficiaries of new credit while others began to struggle, though this was solely due to subsidies, mandates and related programs. As soon as subsequent programmatic changes take effect which became necessary due to «unsustainable» solar growth its credit will also cease.

23. This proves that the only way for the «renewables» sector which was never feasible by itself on the basis of consumer demand - to be "countercyclical» in crisis periods is also via government subsidies. These schemes create a bubble, which is boosted as soon as investors find in «renewables» one of the few profitable sectors while when fleeing other investments. Yet it is axiomatic, as we are seeing now, that when crisis arises, the Government cannot afford this growing subsidy cost either, and finally must penalize the artificial renewable industries which then face collapse.

24. Renewables consume enormous taxpayer resources. In Spain, the average annuity payable to renewables is equivalent to $4.35 \%$ of all VAT collected, $3.45 \%$ of the household income tax, or $5.6 \%$ of the corporate income tax for 2007. 
VI

\section{APPENDIX: DATA USED TO CALCULATE THE GREEN JOBS EFFECTS ON THE ECONOMY}

TABLE 4

WORKING POPULATION

\begin{tabular}{|c|c|}
\hline 1995 & $12,590,000,000$ \\
\hline 1996 & $13,064,400,000$ \\
\hline 1997 & $13,534,500,000$ \\
\hline 1998 & $14,122,000,000$ \\
\hline 1999 & $14,959,800,000$ \\
\hline 2000 & $15,782,300,000$ \\
\hline 2001 & $16,348,200,000$ \\
\hline 2002 & $16,825,400,000$ \\
\hline 2003 & $17,559,700,000$ \\
\hline 2004 & $18,288,100,000$ \\
\hline 2005 & $19,314,300,000$ \\
\hline 2006 & $20,001,800,000$ \\
\hline 2007 & $20,476,900,000$ \\
\hline
\end{tabular}

Source: Encuesta de Población Activa, INE (National Statistics Institute).

TABLE 5

GROSS DOMESTIC PRODUCT

\begin{tabular}{|c|c|c|}
\hline & Current prices & Constant prices (2008) \\
\hline 1995 & $447,205,000,000$ & $706,104,820,634$ \\
\hline 1996 & $473,855,000,000$ & $723,171,461,227$ \\
\hline 1997 & $503,921,000,000$ & $751,148,752,228$ \\
\hline 1998 & $539,493,000,000$ & $784,711,285,453$ \\
\hline 1999 & $579,942,000,000$ & $821,953,191,748$ \\
\hline 2000 & $630,263,000,000$ & $863,460,310,000$ \\
\hline 2001 & $680,678,000,000$ & $894,959,350,000$ \\
\hline 2002 & $729,206,000,000$ & $919,160,979,486$ \\
\hline 2003 & $782,929,000,000$ & $947,621,710,413$ \\
\hline 2004 & $841,042,000,000$ & $978,578,949,814$ \\
\hline 2005 & $908,792,000,000$ & $1,013,947,983,603$ \\
\hline 2006 & $982,303,000,000$ & $1,053,379,393,251$ \\
\hline 2007 & $1,050,595,000,000$ & $1,091,961,721,911$ \\
\hline
\end{tabular}

Source: Cuentas Económicas Anuales, INE. 
TABLE 6

WAGES AND CAPITAL INCOME CONTRIBUTION TO GDP

\begin{tabular}{|c|c|c|}
\hline & Wages & Capital Income \\
\hline 1995 & $48.8 \%$ & $42.6 \%$ \\
\hline 1996 & $49.0 \%$ & $42.3 \%$ \\
\hline 1997 & $49.7 \%$ & $41.3 \%$ \\
\hline 1998 & $49.5 \%$ & $41.1 \%$ \\
\hline 1999 & $49.5 \%$ & $40.6 \%$ \\
\hline 2000 & $49.6 \%$ & $40.5 \%$ \\
\hline 2001 & $49.2 \%$ & $41.2 \%$ \\
\hline 2002 & $48.7 \%$ & $41.6 \%$ \\
\hline 2003 & $48.4 \%$ & $41.6 \%$ \\
\hline 2004 & $47.7 \%$ & $41.9 \%$ \\
\hline 2005 & $47.4 \%$ & $41.7 \%$ \\
\hline 2006 & $47.3 \%$ & $41.6 \%$ \\
\hline 2007 & $47.3 \%$ & $42.3 \%$ \\
\hline
\end{tabular}

Source: Cuentas Económicas Anuales, INE.

TABLE 7

CAPITAL STOCK IN SPAIN

\begin{tabular}{|c|c|c|}
\hline & $\begin{array}{c}\text { Capital Stock at current prices } \\
(2000)\end{array}$ & $\begin{array}{c}\text { Capital stock at constant prices } \\
(2008)\end{array}$ \\
\hline 1995 & $2,426,161,296,831$ & $3,323,840,976,658$ \\
\hline 1996 & $2,506,625,116,773$ & $3,434,076,409,979$ \\
\hline 1997 & $2,592,262,051,117$ & $3,551,399,010,030$ \\
\hline 1998 & $2,690,725,341,078$ & $3,686,293,717,277$ \\
\hline 1999 & $2,802,705,495,030$ & $3,839,706,528,191$ \\
\hline 2000 & $2,924,158,951,252$ & $4,006,097,763,215$ \\
\hline 2001 & $3,051,504,408,335$ & $4,180,561,039,419$ \\
\hline 2002 & $3,182,072,654,259$ & $4,359,439,536,335$ \\
\hline 2003 & $3,319,350,743,153$ & $4,547,510,518,120$ \\
\hline 2004 & $3,462,101,036,701$ & $4,743,078,420,280$ \\
\hline 2005 & $3,618,027,641,919$ & $4,956,697,869,429$ \\
\hline
\end{tabular}

Source: «El stock y los servicios del capital en España y su distribución territoria (19642005). Nueva metodología» by BBVA Foundation and own elaboration based on INE's GDP deflator. 
66 GABRIEL CALZADA, RAQUEL MERINO, JUAN R. RALLO Y JOSÉ I. GARCÍA

TABLE 8

AVERAGE CAPITAL ASSIGNMENT PER WORKER

AT CONSTANT PRICES (2008)

\begin{tabular}{|c|c|}
\hline 1995 & 264,006 \\
\hline 1996 & 262,858 \\
\hline 1997 & 262,396 \\
\hline 1998 & 261,032 \\
\hline 1999 & 256,668 \\
\hline 2000 & 253,835 \\
\hline 2001 & 255,720 \\
\hline 2002 & 259,099 \\
\hline 2003 & 258,974 \\
\hline 2004 & 259,353 \\
\hline 2005 & 256,634 \\
\hline
\end{tabular}

Source: Own elaboration based on INE's and BBVA (Banco Bilbao Vizcaya Argentaria) Research Foundation's publications.

TABLE 9

ROA

\begin{tabular}{lll}
\hline 1995 & & $9.05 \%$ \\
\hline 1996 & & $8.91 \%$ \\
\hline 1997 & & $8.74 \%$ \\
\hline 1998 & $8.75 \%$ \\
\hline 1999 & $8.69 \%$ \\
\hline 2000 & $8.73 \%$ \\
\hline 2001 & $8.82 \%$ \\
\hline 2002 & $8.77 \%$ \\
\hline 2004 & $8.67 \%$ \\
\hline
\end{tabular}

Source: Own elaboration based on INE's and BBVA (Banco Bilbao Vizcaya Argentaria) Research Foundation's publications. 
TABLE 10

AVERAGE PRODUCTIVITY PER WORKER

\begin{tabular}{|c|c|}
\hline 1995 & 27,369 \\
\hline 1996 & 27,124 \\
\hline 1997 & 27,583 \\
\hline 1998 & 27,505 \\
\hline 1999 & 27,197 \\
\hline 2000 & 27,136 \\
\hline 2001 & 26,934 \\
\hline 2002 & 26,605 \\
\hline 2003 & 26,119 \\
\hline 2004 & 25,524 \\
\hline 2005 & 24,884 \\
\hline 2006 & 24,910 \\
\hline 2007 & 25,223 \\
\hline
\end{tabular}

Source: Own elaboration based on INE's data.

TABLE 11

DESTROYED EMPLOYMENT PER RENEWABLE INSTALLED MEGAWATT IN SPAIN 2000-2008

\begin{tabular}{lll}
\hline Wind & 4.27 \\
\hline Mini-hydro & 5.05 \\
\hline Solar & 12.7 \\
\hline Average & 5.06 \\
\hline
\end{tabular}

Source: Own elaboration.

TABLE 12

TAX COLLECTIONS IN SPAIN 2007 BY CATEGORY OF TAX IMPOSED

\begin{tabular}{ll}
\hline VAT related taxes & $64,434,000,000$ \\
\hline Family income tax & $81,299,000,000$ \\
\hline Corporate income tax & $50,065,000,000$ \\
\hline
\end{tabular}

Source: Eurostat. 


\section{BIBLIOGRAPHICAL REFERENCES}

AEE (Wind Entrepreneurial Association)/Deloitte (2008): «Macroeconomic study the impact of the Wind Sector in Spain».

ASIF/APPA (Photovoltaic Industry Association/Renewable Energy Production Association), (2007): «The role of photovoltaic energy in Spain».

ASIF, (2009): «El Ministerio de Industria prolonga la parálisis del Sector Fotovoltaico español», http:/ / www.asif.org/files / ASIF_Industria_prolonga_paralisis_Feb09.pdf

BANK OF SPAIN: «Lending and doubtful lending to finance the productive activities", Statistical bulletin from the Bank of Spain.

CNE (National Energy Commission) (2009a): «Informe mensual de ventas de energía Régimen Especial» («Monthly Report on Energy Purchases from Special Regime»).

- (2009b): «Liquidación provisional n. 13 de 2000». («Provisional Settlement n.. 13 for $2008 »)$.

- (2008): «Tarifas de acceso para 2009 y revision de las tarifas integrales vigentes para el primer trimestre de 2009».

COM (2008): «Proposal for a Directive of the European Parliament and of the Council on the promotion on the use of energy from renewable sources»

- (1997a): «The Energy Dimension of Climate Change»

- (1997b): "Climate Change - The EU Approach to Kyoto»

Directive 2001/77/EC (2001): European Parliament and of the Council.

ENERGíA Y SOCIEDAD (Energy and Society) (2008): «El déficit de tarifa» («The rate deficit»), www.energiaysociedad.es.

EuROPEAN COMMISSION (1997): «Energy for the Future: Renewables Sources of Energy», White Paper for a Community Strategy and Action Plan, http://ec.europa.eu/energy/library/ 599fi_en.pdf

- (2008): «Boosting Growth and Jobs by meeting our Climate Change Commitments», http://europa.eu/rapid/press releasesaction.do?reference $=\mathrm{IP} /$ 08/80\&format)HTML\&Ag $\mathrm{ed}=0 \&$ language $=\mathrm{en} \&$ Guilanguage $=\mathrm{en}$ 
European Trade Confederation (2008a): http://www.etuc.org/ a $/ 4505$.

- (2008b): http://www.etuc.org/a/5667.

EUROSTAT: «Tax collections in Spain 2007 by category of tax imposed». HARVEY BRENNER (2005): «Health Benefits of Low Cost Energy: An Econometric Case Study», Environmental Manager.

HÜlSMANN, Jörg GUIDO (2003): «Facts and Counterfactuals in Economic Law», Journal of Libertarian Studies Vol. 17, n.․ำ pp. 57-102.

ICE REVISTAS («Spanish Trade Information» Journals) (2002): «La industria de la energía eólica en España» («The wind energy industry in Spain»), Economic bulletin n.. 2740.

INE (National Statistics Institute): «Construction Statistics» (20042007).

- «Quarterly National Accounts».

- (2007): «Energy consumption survey».

ISTAS (Union Institute of Work, Environment and Health) (2008): «Estudio Macroeconómico del Sector Eólico en España» («Macroeconomic Study of the Wind Sector in Spain»).

LIZCAÍNO ÁlVAREZ, JESÚs (1995): «Nuevas estrategias de contabilidad de gestión en las empresas multinacionales» («New Management Accounting Strategies for multinational companies»), AECA Bulletin (Número Especial Congreso Sevilla).

Monitoring \& Modelling InITIATIVE ON THE TARGETS FOR ReNEWABLE ENERGY (MITRE). (2003): «Meeting the targets and putting renewables to work».

Morriss, Andrew P., Bogart, William T., Dorchak, ANDrew AND Meiners, Roger E. «Green Jobs Myths» (2009): U Illinois Law \& Economics Research Paper N.․ LE09-001.

RosA, A.Z. et al. (2006): «The Economic Impact of Coal Utilization and Displacement in the Continental United States, 2015», Pennsylvania State University.

Spain. Real Decreto 2818/1998, from December 23rd, Boletín Oficial de Estado (Official State Gazette), n.․312, December $30^{\text {th }}, 1998$.

- $\quad 2366 / 1994$, from December $9^{\text {th }}$ Boletín Oficial del Estado (Official State Gazette), n.ํㅜ 303, December 31 1994. 
70 GABRIEL CALZADA, RAQUEL MERINO, JUAN R. RALLO Y JOSÉ I. GARCÍA

- $\quad 436 / 2004$, from March $12^{\text {th }}$, Boletín Oficial del Estado (Official State Gazette), n. ${ }^{\circ}$ 75, March 27 th, 2004.

- 661/2007, from May 25 ${ }^{\text {th }}$, Boletín Oficial del Estado (Official State Gazette), n.. 126 , May $26^{\text {th }}, 2007$.

- $\quad 578 / 2008$, from September 26th, Boletín Oficial del Estado (Official State Gazette), n. . 234, September 27th 2008.

URIEL JIMÉNEZ, EZEQUIEL et al., (2007): «El stock y los servicios del capital en España (1964-2002). Nueva metodología» («Capital stock and services in Spain and their territorial distribution (1964-2005). New methodology»), BBVA Foundation.

US CENSUS BUREAU, «New residential construction» (2004-2007).

U.S. CONGRESSIONAL BudGet OfFice (2007): «Trade-Offs in Allocating Allowances for CO2 Emissions», Economic and Budget Issue Brief. 